\title{
Advances and Applications of Water Phytoremediation: A Potential Biotechnological Approach for the Treatment of Heavy Metals from Contaminated Water
}

\author{
Cristián Raziel Delgado-González ${ }^{1,+}$, Alfredo Madariaga-Navarrete ${ }^{1,+} \oplus$, José Miguel Fernández-Cortés ${ }^{2} \mathbb{D}$, \\ Margarita Islas-Pelcastre ${ }^{1}$, Goldie Oza ${ }^{3}\left(\mathbb{D}\right.$, Hafiz M. N. Iqbal ${ }^{4, *}$ and Ashutosh Sharma ${ }^{2, *(1)}$ \\ 1 Área Académica de Ciencias Agrícolas y Forestales, Instituto de Ciencias Agropecuarias, \\ Universidad Autónoma del Estado de Hidalgo, Tulancingo 43600, Mexico; \\ cristian_delgado@uaeh.edu.mx (C.R.D.-G.); alfredo_madariaga@uaeh.edu.mx (A.M.-N.); \\ mislas@uaeh.edu.mx (M.I.-P.) \\ 2 Centre of Bioengineering, School of Engineering and Sciences, Tecnologico de Monterrey, \\ San Pablo 76130, Mexico; A01208134@itesm.mx \\ 3 Centro de Investigación y Desarrollo Tecnológico en Electroquímica (CIDETEQ), Parque Tecnológico, \\ Pedro Escobedo 76703, Mexico; goza@cideteq.mx \\ 4 School of Engineering and Sciences, Tecnologico de Monterrey, Monterrey 64849, Mexico \\ * Correspondence: hafiz.iqbal@tec.mx (H.M.N.I.); asharma@tec.mx (A.S.) \\ check for \\ updates \\ + Equal contribution.
}

Citation: Delgado-González, C.R. Madariaga-Navarrete, A.;

Fernández-Cortés, J.M.;

Islas-Pelcastre, M.; Oza, G.; Iqbal, H.M.N.; Sharma, A. Advances and Applications of Water Phytoremediation: A Potential Biotechnological Approach for the Treatment of Heavy Metals from Contaminated Water. Int. J. Environ. Res. Public Health 2021, 18, 5215 https://doi.org/10.3390/ ijerph18105215

Academic Editor: Paul B. Tchounwou

Received: 30 March 2021

Accepted: 12 May 2021

Published: 14 May 2021

Publisher's Note: MDPI stays neutral with regard to jurisdictional claims in published maps and institutional affiliations.

Copyright: (c) 2021 by the authors Licensee MDPI, Basel, Switzerland. This article is an open access article distributed under the terms and conditions of the Creative Commons Attribution (CC BY) license (https:// creativecommons.org/licenses/by/ $4.0 /)$

\begin{abstract}
Potable and good-quality drinking water availability is a serious global concern, since several pollution sources significantly contribute to low water quality. Amongst these pollution sources, several are releasing an array of hazardous agents into various environmental and water matrices. Unfortunately, there are not very many ecologically friendly systems available to treat the contaminated environment exclusively. Consequently, heavy metal water contamination leads to many diseases in humans, such as cardiopulmonary diseases and cytotoxicity, among others. To solve this problem, there are a plethora of emerging technologies that play an important role in defining treatment strategies. Phytoremediation, the usage of plants to remove contaminants, is a technology that has been widely used to remediate pollution in soils, with particular reference to toxic elements. Thus, hydroponic systems coupled with bioremediation for the removal of water contaminants have shown great relevance. In this review, we addressed several studies that support the development of phytoremediation systems in water. We cover the importance of applied science and environmental engineering to generate sustainable strategies to improve water quality. In this context, the phytoremediation capabilities of different plant species and possible obstacles that phytoremediation systems may encounter are discussed with suitable examples by comparing different mechanistic processes. According to the presented data, there are a wide range of plant species with water phytoremediation potential that need to be studied from a multidisciplinary perspective to make water phytoremediation a viable method.
\end{abstract}

Keywords: hazardous pollutants; toxic elements; removal mechanisms; bioremediation; biodiversity; water

\section{Introduction}

One of the current challenges due to the global population is providing clean water to the whole world. According to the World Health Organization (WHO) [1], around 2.2 billion people use non-potable and untreated water services from highly unsafe water resources. Some examples of studies in water pollution [2,3] have registered the potential impact of water contamination by heavy metals (HMs), demonstrating a high risk for health issues, such as carcinogenicity and other diseases, associated with polluted water bodies. To keep providing safe and clean water to every person globally, maintenance and 
infrastructure need to be assured. However, underdeveloped countries often do not have access to services that ensure water quality for distribution and human consumption [4].

The Water Quality Index and other indexes help to understand factors that may influence water quality and make decisions on drinking water quality based on the criteria, such as $\mathrm{pH}$, microorganisms in water, persistence of organochlorides, and heavy metals (HMs), among others [5,6], but not every country has access to water that meets the proposed criteria [7].

The sources of water contamination may be diverse. Nevertheless, they can be grouped into four broad categories: pathogens, inorganic compounds, organic material, and macroscopic pollutants. Inorganic and organic contaminants are the most common, even in treated water $[8,9]$. Furthermore, inorganic pollutants are more persistent in both waste and treated waters [10-17]. According to the WHO [1], HMs contaminate water, with mercury $(\mathrm{Hg})$, cadmium $(\mathrm{Cd})$, arsenic $(\mathrm{As})$, chromium $(\mathrm{Cr})$, and lead $(\mathrm{Pb})$, among other heavy metals, having a long persistence in the environment. Heavy metal contamination is detrimental to health after prolonged consumption, being linked to conditions such as behavioral disorders, respiratory problems [18], oxidative stress cause by reactive oxygen species (ROS) [19], and immune, skin, respiratory, and endocrine diseases [20], among others. By acknowledging these statistics, we can recognize contaminated water as a global issue that needs to be addressed.

However, the variety of effects a pollutant can cause depends on the nature of the contaminant. HMs represent some of the most common and hazardous pollutants, widespread in soil and water. Some of them (such as $\mathrm{Cu}, \mathrm{Ni}, \mathrm{Mn}, \mathrm{Zn}$, and $\mathrm{Co}$ ) play an important role in plant metabolism [21]. Many others are hazardous elements to both plants and animals, according to data presented by the United States Environmental Protection Agency [22]. $\mathrm{HMs}$ such as $\mathrm{As}, \mathrm{Hg}, \mathrm{Cr}, \mathrm{Cd}$, and $\mathrm{Pb}$ can cause hazardous effects in the cardiovascular, dermal, respiratory, and digestive systems, and many other pollutants cause diverse health effects, including asthma, diabetes, cancer, and Parkinson's disease [23].

Electrochemical, chemical, and physical techniques are used to treat some contaminants, but may not reduce them. Soil leaching, adsorption, and nano-sorbents are some of the strategies that remove metals from soil [24]. This is why emerging technologies, such as bioremediation, can be implemented to improve remediation systems-for example, the usage of plants to remove some of the most common pollutants in water. In this review, we address the importance of water phytoremediation techniques for heavy metal (HM) pollutants, analyzing previous studies, specific plant species, biological processes, developed technologies based on patents and the current needs and research gaps.

\section{Materials and Methods}

A total of 435 articles were analyzed, but only 170 from 2000 to 2020 were discussed as a part of the phytoremediation systems review, following the year of publication, evidence of phytoremediation, properly described physiological process, and positive results on the removal of the contaminant. However, studies that may not include adequately described methods or supported results were excluded. We used PubMed, SCOPUS and other free data search tools to look for relevant articles, using the following keywords: water phytoremediation, phytoremediation mechanisms, water plants, and water pollutants, selecting 40 different species from 22 families for further analysis, according with the mobilization of HM results and the adequate explained methodology. Non-parametric estimators of species richness were used in Estimates (9.1.0) to determine an approximate number of species associated with phytoremediation processes in water to assure the representativeness of the data $[25,26]$. A search in Google Patents was conducted to compare the 40 selected species, with the total of patents associated with each species. Only water phytoremediation-related patents were considered for this comparison. 


\section{Results and Discussion}

Phytoremediation has been primarily used to treat soil pollutants [27-30]. With emerging hydroponic methods and a mechanistic approach [31], the usage of plants to bioremediate water has become more available. However, to establish a replicating water phytoremediation model, the morphological and physiological traits associated with the pollutant uptake, compartmentalization, volatilization, filtration, and many other processes must be understood. Many studies (Table 1) have shown the importance of plants for treating pollutants, both inorganic and organic, even those pollutants that might be recalcitrant or difficult to metabolize. HMs represent important pollutants that may remain in water and sediments [32], that different strategies try to treat [33]. However, phytoremediation represents an emerging technology that can help in HM removal [34].

Table 1. Data from 40 species analyzed in studies related to phytoremediation in water. The presented data were published in studies between 2000 and 2020.

\begin{tabular}{|c|c|c|c|c|c|c|}
\hline Plant Species & Family & Country & $\begin{array}{l}\text { Contaminants } \\
\text { Treated }\end{array}$ & $\begin{array}{l}\text { Phytoremediation } \\
\text { Process }\end{array}$ & Results & References \\
\hline Arundo donax & Poaceae & Pakistan & As & Phytoextraction & $\begin{array}{l}\text { Removal of at least } 15 \% \text { of the } \\
\text { pollutant in the treatment of } \\
\qquad 600 \mu \mathrm{g} \mathrm{L}^{-1}\end{array}$ & [35] \\
\hline Azolla caroliniana & Salvi-niaceae & India & $\begin{array}{l}\text { Heavy metals in } \\
\text { metal enriched fly } \\
\text { ash pond }(\mathrm{Cr}, \mathrm{Pb} \text {, } \\
\mathrm{Cu} \text { and } \mathrm{Ni})\end{array}$ & Phytoaccumula-tion & $\begin{array}{l}\text { High sequestration of metals } \\
\text { (175-538 and } 86-753 \mathrm{mg} \mathrm{kg}^{-1} \\
\text { plant tissue) BCF } 1.7-18.6 \text { and } \\
1.8-11.0 .\end{array}$ & [36] \\
\hline Azolla filiculoides & Salvi-niaceae & Chile, Israel & $\mathrm{Cd}, \mathrm{Cu}, \mathrm{Pb}$ & Phytoextraction & $\begin{array}{l}\text { High concentration in plant } \\
\text { tissues, more than } 1000 \\
\text { micrograms per } \mathrm{kg}^{-1}\end{array}$ & {$[37,38]$} \\
\hline Azolla pinnata & Salvi-niaceae & India, Nigeria & $\mathrm{Hg}, \mathrm{Cd}, \mathrm{Zi}, \mathrm{Fe}$ & Phytoextraction & $\begin{array}{c}\text { Metal content decreased to } \\
70-94 \% \text {, there is no significant } \\
\text { removal of Fe, but Zi decreased } \\
\text { more than } 30 \%\end{array}$ & [39] \\
\hline Canna indica & Cannaceae & India & $\mathrm{F}$ & Phytoaccumula-tion & $95 \%$ fluoride removal & {$[40]$} \\
\hline $\begin{array}{l}\text { Ceratophyllum } \\
\text { demersum }\end{array}$ & Ceratophyllaceae & Egypt & $\mathrm{Cr}, \mathrm{Pb}$ & Phytoaccumula-tion & $\begin{array}{l}95 \% \text { removal of lead and } 84 \% \\
\text { of chromium }\end{array}$ & {$[41]$} \\
\hline Cyperus alternifolius & Cyperaceae & India & $\mathrm{F}$ & Phytoaccumula-tion & $65 \%$ fluoride removal & {$[40]$} \\
\hline Eichhornia crassipes & Pontederiaceae & India, Nigeria & $\begin{array}{l}\text { As, } \mathrm{Hg}, \mathrm{Ni}, \mathrm{Pb}, \mathrm{Zn}, \\
\mathrm{Cu}, \mathrm{Ag}\end{array}$ & Phytoaccumula-tion & $\begin{array}{l}\text { Acummulation from } 26 \mathrm{mg} / \mathrm{kg} \\
\text { to } 327 \mathrm{mg} / \mathrm{kg} \text { in dry weight }\end{array}$ & {$[42,43]$} \\
\hline Eleocharis acicularis & Cyperaceae & Japan & $\mathrm{Cu}, \mathrm{Zn}, \mathrm{As}, \mathrm{Cd}, \mathrm{Pb}$ & Phytoextraction & $\begin{array}{l}\text { Remotion higher than } 90 \% \text { of } \\
\text { the heavy metals }\end{array}$ & [44] \\
\hline Helianthus annuus & Asteraceae & Pakistan & $\mathrm{Ni}, \mathrm{Pb}$ & Phytoextraction & $\begin{array}{l}\text { More than } 50 \% \text { of removal, } \\
17 \mathrm{mg} \mathrm{Kg}^{-1} \text { in plant tissue }\end{array}$ & [45] \\
\hline Hydrilla verticillata & $\begin{array}{l}\text { Hydro- } \\
\text { charitaceae }\end{array}$ & India, China & $\begin{array}{l}\text { F, As, and other } \\
\text { heavy metals }\end{array}$ & $\begin{array}{l}\text { Phytoaccumula-tion, } \\
\text { Phyto-degradation }\end{array}$ & $\begin{array}{l}\text { Maximum removal } 24.4 \% \text { at } \\
2.5 \text { ppm without dramatically } \\
\text { affecting associated } \\
\text { physiological parameters, and } \\
\text { the resultant degradation } \\
\text { products are non-toxic }\end{array}$ & [46-48] \\
\hline Ipomoea aquatica & Convolvulaceae & Iran, Sri Lanka & $\mathrm{Pb}, \mathrm{Cr}$ & Rhizofiltration & $\begin{array}{l}\text { The highest } \mathrm{BCF}(4179.07) \text { value } \\
\text { was registered in root tissue } \\
\left(0.63 \mathrm{mg} \mathrm{L}^{-1} \mathrm{~Pb}\right) \text { More than } 90 \% \\
\mathrm{Cr}(\mathrm{VI}) \text { sequestrated in leaves } \\
\text { and steams. In none of the } \\
\mathrm{Cr}(\mathrm{VI}) \text { dosing experiments did } \\
\text { the I. aquatica show } \\
\text { toxicity symptoms. }\end{array}$ & {$[49,50]$} \\
\hline Iris pseuda-corus & Iridaceae & Spain & $\mathrm{Cr}, \mathrm{Zn}$ & Rhizofiltration & $\begin{array}{c}59.97 \mathrm{mg} \mathrm{Cr} \text { and } 25.64 \mathrm{mg} \mathrm{Zn} \\
\text { in roots }\end{array}$ & {$[51]$} \\
\hline Juncus effusus & Juncaceae & China & $\mathrm{Pb}$ & Phytodegradation & $\begin{array}{l}\text { Concentrations higher than } \\
2000 \mathrm{mg} \mathrm{kg}^{-1} \text { in roots }\end{array}$ & [52] \\
\hline Lemna gibba & Araceae & Germany & $\mathrm{U}, \mathrm{As}$ & Phytoextraction & $\begin{array}{l}\text { Accumulation in plant tissue, } \\
\text { around } 500 \mathrm{mg} \mathrm{kg}^{-1}\end{array}$ & [53] \\
\hline Lemna minor & Araceae & Pakistan, Iran & $\begin{array}{l}\text { Heavy metals in } \\
\text { contaminated } \\
\text { effluents }\end{array}$ & Phytoaccumula-tion & $\begin{array}{l}\text { Considerable reduction in every } \\
\text { metal in municipal effluent }\end{array}$ & [27] \\
\hline Lepironia articulata & Cyperaceae & USA & $\mathrm{Pb}$ & Rhizofiltration & $\begin{array}{l}\text { More than } 500 \mathrm{mg} / \mathrm{kg} \text { in its } \\
\text { plant tissue (roots) and } 217 \text { of } \\
\text { BCF value }\end{array}$ & [54] \\
\hline
\end{tabular}


Table 1. Cont.

\begin{tabular}{|c|c|c|c|c|c|c|}
\hline Plant Species & Family & Country & $\begin{array}{l}\text { Contaminants } \\
\text { Treated }\end{array}$ & $\begin{array}{l}\text { Phytoremediation } \\
\text { Process }\end{array}$ & Results & References \\
\hline Lolium perenne & Poaceae & France & $\mathrm{Cr}$ & Phytostabilization & $\begin{array}{l}\text { High accumulation in roots, } \\
\text { higuer than } 2000 \mu \mathrm{g}^{-1} \mathrm{DW}\end{array}$ & [55] \\
\hline Ludwigia stolonifera & Onagra-ceae & Egypt & $\mathrm{Cd}, \mathrm{Ni}, \mathrm{Zn}, \mathrm{Pb}$ & Phytostabilization & $\begin{array}{l}\text { Bioaccumulation and } \\
\text { translocation factor showed } \\
\text { positive interaction for the } \\
\text { uptake of metals highlighted }\end{array}$ & [56] \\
\hline Mentha aquatica & Lamiaceae & Lebanon & $\mathrm{Ni}$ & Rhizofiltration & $\begin{array}{l}8327 \mathrm{mg} \mathrm{kg}^{-1} \text { accumulated } \\
\text { mainly in root tissue }\end{array}$ & [57] \\
\hline $\begin{array}{l}\text { Myrio-phyllum } \\
\text { aquaticum }\end{array}$ & Haloragaceae & Italy & $\mathrm{Cd}, \mathrm{Cr}, \mathrm{Ni}, \mathrm{Zn}$ & Phytoaccumulation & $\begin{array}{l}\text { High accumulation in plant } \\
\text { tisssue at high concentrations, } \\
\text { more than } 500 \mathrm{\mu g} \mathrm{g}^{-1} \mathrm{DW}\end{array}$ & [58] \\
\hline $\begin{array}{l}\text { Myrio-phyllum } \\
\text { triphyllum }\end{array}$ & Haloragaceae & Turkey & $\mathrm{Cd}$ & Phytoaccumu-lation & $\begin{array}{c}17.03 \mu \mathrm{g} \text { Cd accumulation was } \\
\text { found in a gram in } \\
\text { dried sample }\end{array}$ & [59] \\
\hline $\begin{array}{l}\text { Myrio-phyllum } \\
\text { elatinoides }\end{array}$ & Haloragaceae & China & B & Phytoaccumulation & $\begin{array}{c}\text { Maximal tissue accumulation in } \\
\text { shoot tissue and root section } \\
(1296.5 \text { and } 350.7 \mathrm{mg} / \mathrm{kg} \\
\text { each one })\end{array}$ & [60] \\
\hline Nelumbo nucifera & Nelum-bona-ceae & India & $\begin{array}{l}\mathrm{Cd}, \mathrm{Co}, \mathrm{Cu}, \mathrm{Ni}, \mathrm{Pb} \\
\text { and } \mathrm{Zn}\end{array}$ & Phytoextraction & $\begin{array}{l}\text { Accumulation in tissue more } \\
\text { than } 340 \text { ppm of metals }\end{array}$ & {$[61]$} \\
\hline Oenanthe javanica & Apiaceae & USA & $\mathrm{Hg}$ & Phytoaccumulation & $\begin{array}{l}\text { More than } 1 \mathrm{mg} / \mathrm{kg} \text { remediated } \\
\text { and } 807 \text { of } \mathrm{BCF} \text { value }\end{array}$ & [62] \\
\hline Phragmites australis & Poaceae & $\begin{array}{l}\text { Saudi Arabia, } \\
\text { Denmark }\end{array}$ & $\mathrm{Cd}, \mathrm{Pb}, \mathrm{Ni}$ & Rhizofiltration & $\begin{array}{l}\text { High concentration in roots, } \\
\text { more than } 3 \mathrm{mg} \mathrm{kg}^{-1}\end{array}$ & [63] \\
\hline Pistia stratiotes & Araceae & USA, India & $\mathrm{Cd}, \mathrm{Cu}, \mathrm{Fe}, \mathrm{Hg}$ & $\begin{array}{l}\text { Phytoextraction and } \\
\text { rhizofiltration }\end{array}$ & $\begin{array}{l}\text { Accumulation of } \mathrm{Cd} \text { in roots } \\
\left.\text { (more than } 10 \mathrm{mg} \mathrm{kg}^{-1}\right), \mathrm{Cu}, \mathrm{Fe} \\
\text { and } \mathrm{Hg} \text { concentrations from } 1 \\
\text { to } 15 \mathrm{mg} \mathrm{kg}^{-1} \mathrm{DW} .\end{array}$ & {$[64,65]$} \\
\hline Plantago major & Plantaginaceae & Switzerland & $\mathrm{Pb}$ & Rhizofiltration & $\begin{array}{l}\text { High uptake, more than } \\
20 \mathrm{mg} / \mathrm{kg} \text { of } \mathrm{Pb} \text { in root tissue }\end{array}$ & {$[66]$} \\
\hline Potamo-geton natans & Potamogetonaceae & Sweden & $\mathrm{Zn}, \mathrm{Cu}, \mathrm{Cd}, \mathrm{Pb}$ & Rhizofiltration & $\begin{array}{l}\text { Highest accumulation found in } \\
\text { the roots }\end{array}$ & {$[67]$} \\
\hline Pteris vittata & Pteridaceae & USA & As & Phytoaccumulation & $\begin{array}{c}\text { Reduced arsenic concentration } \\
\text { by } 98.6 \%\end{array}$ & [68] \\
\hline Salvinia biloba & Salviniaceae & Brazil & $\mathrm{Pb}$ & Phytoextraction & Almost $90 \%$ of $\mathrm{Pb}$ remotion & [69] \\
\hline Salvinia minima & Salviniaceae & Mexico & $\mathrm{Pb}$, As & Phytoaccumu-lation & $\begin{array}{l}\text { More than } 34 \mathrm{mg} / \mathrm{g} \mathrm{Pb} \text { in dry } \\
\text { weight tissue and high As } \\
\text { uptake, with } 0.5 \mathrm{mg} / \mathrm{g} \mathrm{DW}) .\end{array}$ & [70] \\
\hline Salvinia molesta & Salviniaceae & Brazil & As & Phytoaccumu-lation & $\begin{array}{l}\text { Accumulation in leaves, } \\
\text { highest accumulation } \\
148.63 \mathrm{~g} \mathrm{~g}^{-1} \mathrm{DW}\end{array}$ & {$[71]$} \\
\hline Salvinia natans & Salviniaceae & India & $\mathrm{Zn}, \mathrm{Cu}, \mathrm{Ni}, \mathrm{Cr}$ & Phytoaccumu-lation & $\begin{array}{l}\text { High removal, more than } 50 \% \\
\text { average for each metal }\end{array}$ & [72] \\
\hline Spirodela polyrhiza & Araceae & Japan & As & Phytoaccumu-lation & $\begin{array}{l}\text { Accumulations on DW tissue } \\
\text { higher than } 0.35 \mu \mathrm{mol} / \mathrm{g} \text { for } \\
\text { arsenate and around } \\
7.6 \mathrm{nmol} / \mathrm{g} \text { DW for DMAA }\end{array}$ & [73] \\
\hline Trapa natans & Lythraceae & India & $\begin{array}{l}\text { Heavy metals in } \\
\text { wastewater }\end{array}$ & Phytoaccumu-lation & $\begin{array}{l}\text { Metal contents translocated in } \\
\text { leaves, whereas most contents } \\
\text { of } \mathrm{Cr} \text { and } \mathrm{Pb} \text { were accumulated } \\
\text { in the root. }\end{array}$ & [74] \\
\hline Typha domin-gensis & Typhaceae & Egypt, Brazil & $\mathrm{P}, \mathrm{Na}, \mathrm{K}, \mathrm{Zn}, \mathrm{Hg}$ & Phytoextraction & $\begin{array}{l}\text { Reduced } \mathrm{P}, \mathrm{Na}, \mathrm{K} \text { almost in } \\
80 \% \text {, reduced } \mathrm{Zn} \text { in } 10 \% \text { with } \\
\text { respect to initial values, } \\
\text { Reduces } 99.6 \pm 0.4 \% \text { of the } \\
\text { mercury in contaminated water }\end{array}$ & {$[75,76]$} \\
\hline Typha latifolia & Typhaceae & Italy & $\mathrm{Cu}, \mathrm{Zn}$ & Phytoextraction & $\begin{array}{l}\text { Higher accumulation of Zinc, } \\
\text { more than } 55 \mathrm{mg} \mathrm{Kg} \mathrm{DW} \mathrm{in} \\
\text { root tissue }\end{array}$ & [77] \\
\hline Vallisneria natans & Hydrocharitaceae & China & As & Rhizo-filtration & $\begin{array}{c}\text { High accumulation in roots } \\
\text { (more than } 200 \mathrm{mg} / \mathrm{kg}^{-1} \mathrm{DW} \text { of } \\
\text { As (IV)) }\end{array}$ & [78] \\
\hline Wolffia globosa & Araceae & China, Thailand & As, $\mathrm{Cd}, \mathrm{Cr}$ & $\begin{array}{l}\text { Phyto-accumu- } \\
\text { lation }\end{array}$ & $\begin{array}{l}\text { Accumulate more than } 1000 \mathrm{mg} \\
\text { As kg }^{-1} \text { in DW tissue, Max } \\
\text { accumulation Cd } 5931 \mu \mathrm{g} / \mathrm{g} \\
\text { DW. } 3500 \mu \mathrm{g} / \mathrm{g} \mathrm{DW} \mathrm{Cr}\end{array}$ & {$[79,80]$} \\
\hline
\end{tabular}


Biodiversity is a point that needs to be explored in water phytoremediation systems, since diversity may infer different metabolic pathways, resistance and mobilization of HM characteristics in plants [81-83]. Since there are several diseases associated with these pollutants, and each of them may vary in its bioavailability and chemical structure, different mechanisms and plants have to be used to remove these pollutants. The five most representative plant families (Table 1, Figure 1) were Salviniaceae, Araceae, Cyperaceae, Haloragaceae, and Poaceae, which together conform to almost $55 \%$ of the total plant species. This allows us to infer that knowledge of plants and their usage as phytoremediators in water needs to be extended, since the number of plant species reported is more than 374,000 in total and is increasing each year [84].

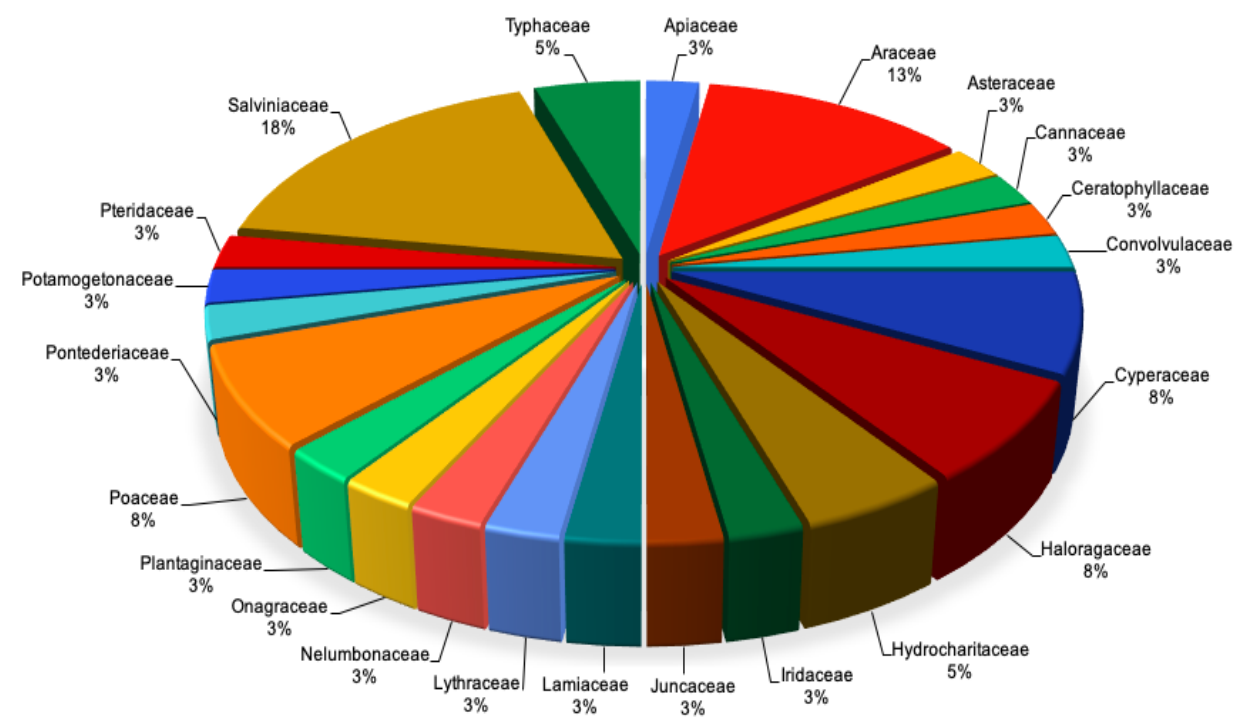

Figure 1. Twenty-two families corresponding to 40 species reviewed in the present study reported due their water phytoremediation capacity. The higher the percentage, the higher the representation in the analysis, implying more species for each family. References are listed in Table 1.

Salviniaceae, the most representative family, with almost $18 \%$ of the total species, is characterized by free-floating plants. Even though most of the species lack a developed root system [85], several studies reported their water phytoremediation capability. The two genera within the family are represented in the review, Azolla and Salvinia spp., but only 6 out of the 16 total reported species have been studied under phytoremediation criteria $[85,86]$. The second family with the most presented species is Araceae, with almost $13 \%$ of the 40 reported plants. However, in this family, there are 3800 published species with 102 genera, according to the most recent family-wide molecular phylogeny published in 2008 [87]. By comparing the results of Table 1, we can observe only five species out of the total 3800 reported species that have been studied, and only four genera from the 102 previously reported. The last three most representative families, with almost $8 \%$ of the total diversity, are Cyperaceae, Haloragaceae, and Poaceae.

This means that the $24 \%$ of the total species are represented by the Magnoliophyta division, and comparing the total species of each family, less than $5 \%$ of the total reported species have been analyzed under phytoremediation criteria [88-91]. One of the data's common factors is the lack of research related to phytoremediation, in contrast with the total number of registered species worldwide. Only a few species from the same genera or family have similar phytoremediation properties. This means that there is a high probability of their usefulness in water phytoremediation systems. From the data presented above, we can find that only $15 \%$ of the total species (6 out of the 40 ) are terrestrial plants, which means that their water requirements are lower than the other $85 \%$ of the plants from the table. However, the radicular system can be modified and adapted to 
water conditions [92,93], which may be one important factor to allow the filtration and mobilization of the contaminants from the water to plant tissue.

The present study considers research focused mainly on hydroponic controlled systems; even though constructed wetland studies have shown an important removal of HMs [94,95], the source of the water, mainly wastewater [95,96], and other non-controlled variables may affect the evaluation of the actual participation of the plant inside the system, such as interaction with other contaminants [97] and positive or negative interactions between different native plants species [98], among others. The comparison in the present review is focused on studies that can be compared likewise, with most of the variables under control, such as $\mathrm{pH}$ and temperature, among others. The physiology and mechanisms of mobilization for each plant may be similar, but many differences need to be addressed to understand the overall phytoremediation system in depth.

\section{Mechanistic Approach}

Plants are viable for use in the remediation of the organic and inorganic pollutants. (Figure 2) [99]. Based on the process and application, phytoremediation has been commonly divided into the following mechanisms, i.e., rhizofiltration, phytovolatilization, phytodegradation, phytostabilization and phytoextraction [100-107]. The phytoremediation capacity of a plant depends on the molecular and physiological mechanisms [105]. In the same way, understanding the biological processes implicated in the phytoremediation technique is imperative to improve their efficiency [103], which implies significant tolerance to pollutants, greater accumulation capacity [99], higher plant yield and significant pollutant uptake [104]. We discuss below the main properties for each technique applied to phytoremediation mechanistically.

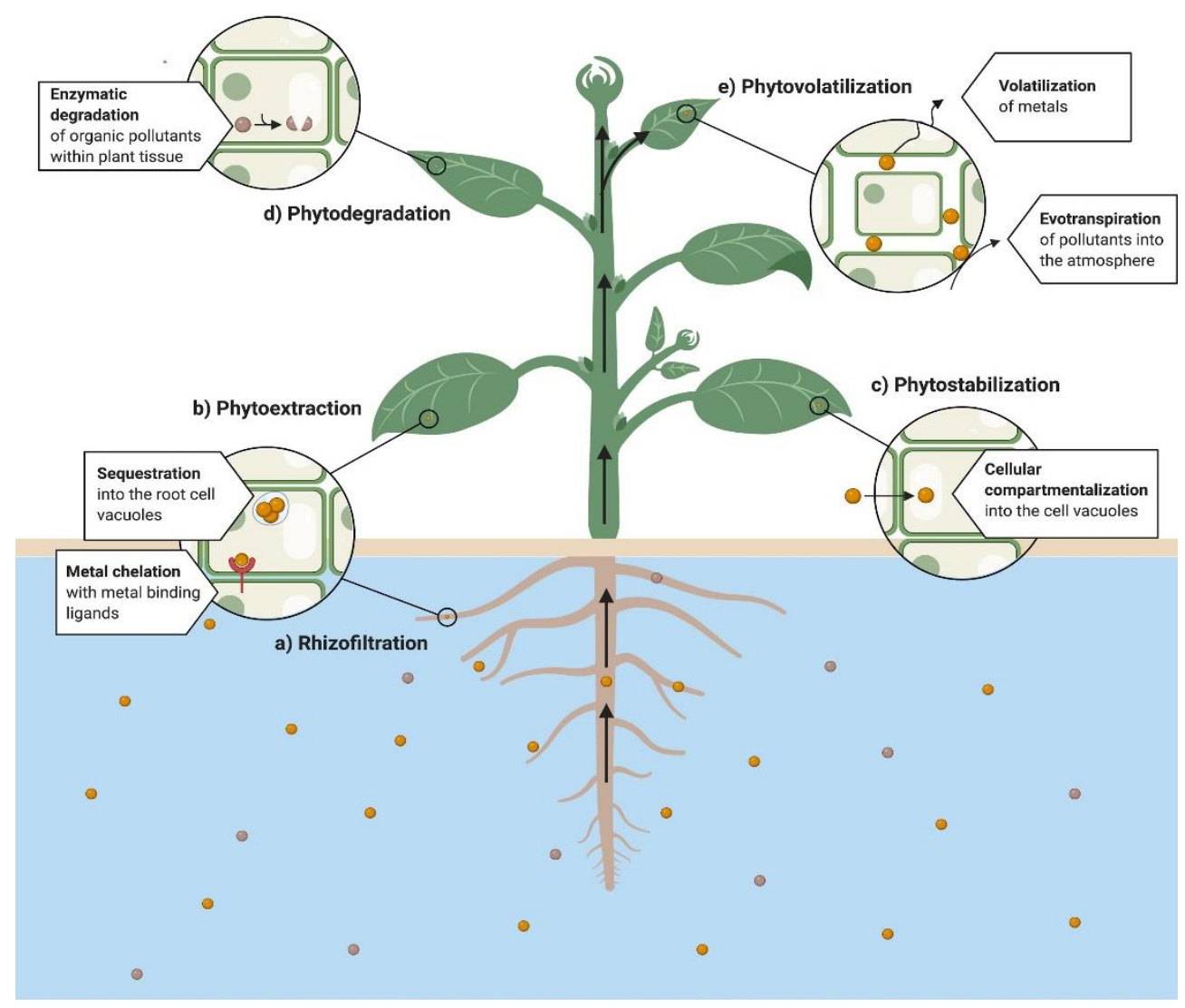

Figure 2. General diagram of phytoremediation processes in water. 


\subsection{Phytoextraction}

The amount of HM that a plant can accumulate is determined by the capacity of the plant species to sequester the compound or metal and the intercellular mobilization through the plant [104]. Accumulation is a complex process that involves several steps, which include heavy metal transportation through the plasma membrane of root cells, xylem loading, translocation, sequestration, and detoxification at cellular levels in the whole plant [108]. During the absorption, pollutants' bioavailability can be enhanced through rootassociated microorganisms [109] and root exudates [110], and even in hydroponic cultures, microorganisms can establish a symbiotic relationship with the plant's roots $[111,112]$. There are several reports about the potential of specific plants for metal phytoextraction in water that can be compared with the current knowledge of the physiological traits $[35,75]$ (Figure 3).

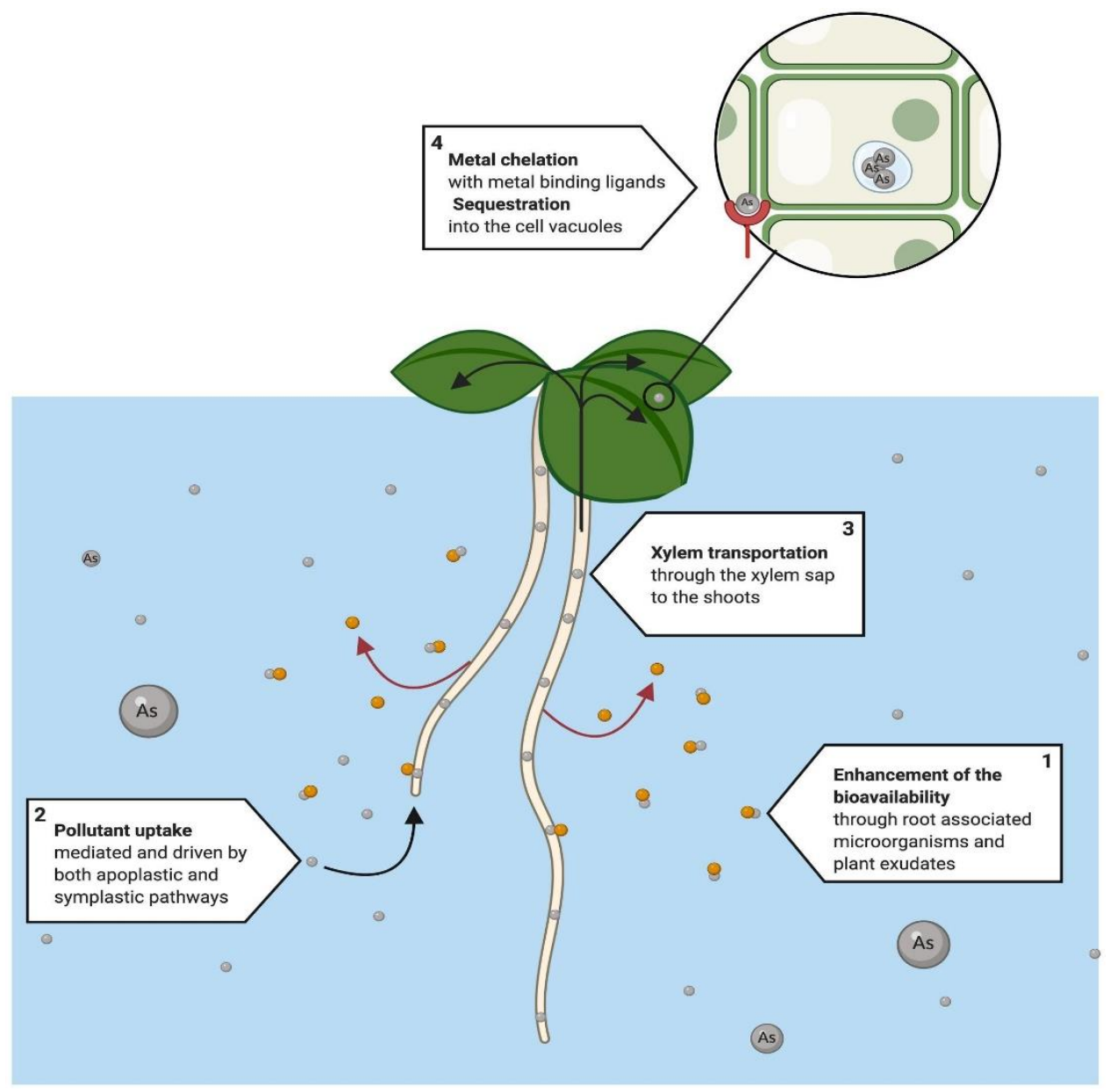

Figure 3. Proposed phytoextraction system that has been mainly used for the removal of heavy metals, such as arsenic (As). The process initiates with the root uptake of the metals (1). Prior to absorption, (2) the bioavailability of metals can be enhanced through root associated microorganisms and plant root metabolites, to improve in the phytoextraction process. Once the metal is available, (3) it is mobilized to shoots and leaves, through the xylem sap. Finally, (4) the pollutant is chelated and sequestered by the cell into the cell vacuoles where it will later will be harvested within the plant tissue for proper disposal [113-115].

\subsection{Rhizofiltration}

Rhizofiltration (Figure 4) occurs when plant roots remove pollutants, principally metals, from an aqueous substrate [116]. It involves the absorption, adsorption [99], and precipitation of pollutants from the substrate [116], which first take place in the root surface 
through different interrelated physicochemical processes, such as chelation, ion exchange, and chemical precipitation through root exudates, among others [116].

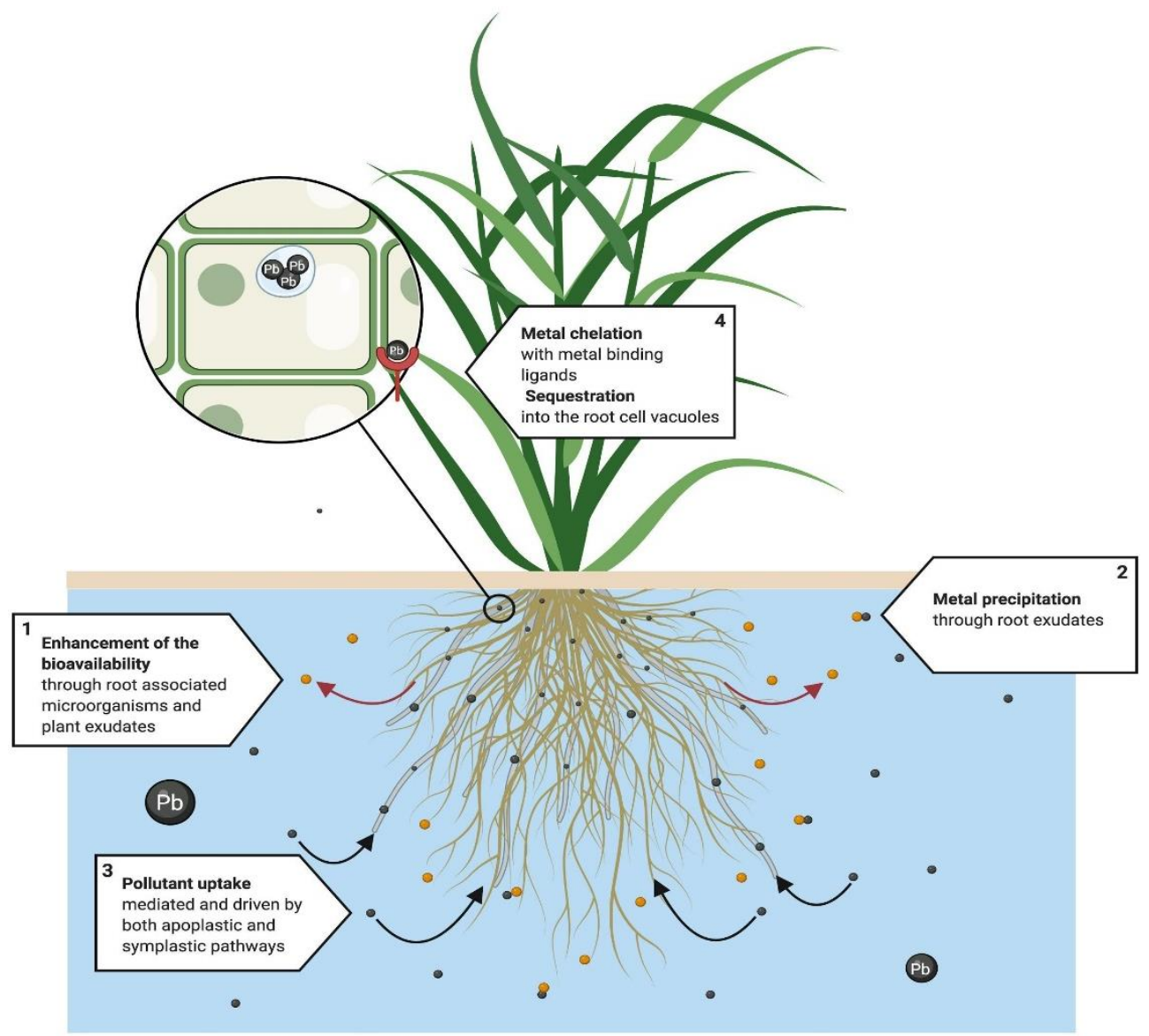

Figure 4. Proposed rhizofiltration system. This technique is mainly used in metal phytoremediation. From a physiological perspective, root exudates and microorganisms (1) enhance bioavailability, followed by (2) the precipitation of metals. (3) Pollutant uptake is mediated and driven by both apoplastic and symplastic pathways. If symplastic pathways fail to translocate the pollutant into leaves and steam, chelation and sequestration takes place mainly in the roots of the plant. (4) Metals are chelated by metal binding ligands, phytochelatins and metalloteines, and finally pollutants are either sequestered into the cell vacuoles and the apoplast or bound to the cell wall [114-117].

Metal uptake in the roots occurs under the same mechanisms as in the phytoextraction process. However, for the rhizofiltration process, the translocation in the plant cannot be achieved efficiently since the contaminant accumulates mainly in root tissue [114]. After its uptake and mobilization, the pollutant is stored in the vacuoles and the apoplast, or covalently bonded to the cell walls [117], after being chelated by phytochelatins and metallothioneins [115]. Evidence of metal rhizofiltration in water has been shown in several studies $[64,78]$, with high concentrations in root tissue $[63,66]$.

\subsection{Phytodegradation}

Pollutants can either be entirely mineralized into inorganic compounds or degraded to a stable, less toxic intermediate that is attracted by the cell wall or sequestered by the vacuoles [118]. Enzymes serve as biological catalysts for degradation within the plant tissue [119]. Rhizosphere pollutant degradation improves with an increased microbial metabolic activity and growth, which are enhanced by plant exudates [111,112,120,121]. Thus, plant-microbe interactions are an essential mechanism to achieve the degradation of organic pollutants [122-124]. Many examples of the participation of phytodegradation 
have been reported, which helps us to understand the physiological dynamics and the metabolic pathways that are associated with it $[47,125]$ (Figure 5).

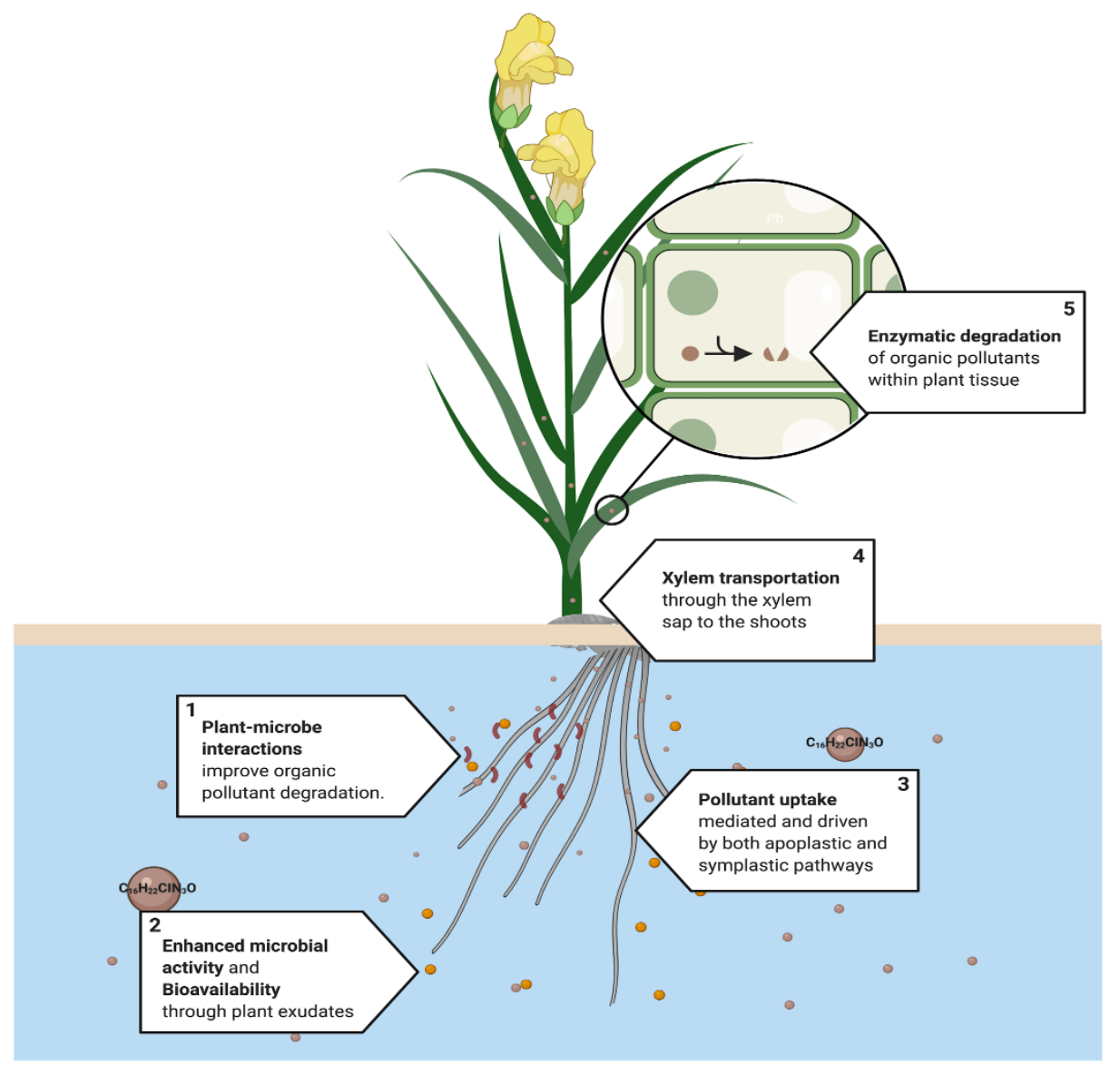

Figure 5. Proposed phytodegradation system. This process is used mainly in the phytoremediation of organic pollutants, such as tebuconazole C16H22CIN2O. (1) Plant-rhizosphere interactions improve the degradation of organic pollutants. (2) Root exudates increase the bioavailability and enhance rhizospheric activity, (3) followed by pollutant uptake, which occurs in the roots and is mediated by apoplastic and symplastic pathways. (4) Then, organic pollutants can be transported to mainly leaves or the roots through the xylem sap to finally (5) be metabolized in the cell to less toxic compounds by the action of plant enzymes. [111,112,120,121].

\subsection{Phytostabilization}

This is a process occurring in the rhizosphere (Figure 6) to stabilize and immobilize pollutants from the substrate [126], which is the principal advantage of this technique considering that there is no need for harvesting from the source location [127]. This process is compatible with the sequestration of pollutants, mainly metals, within the rhizosphere [111,112,126].

Some of the studies reviewed showed a relation between the pollutant characteristics and the plant physiology, such as nutrient uptake, chlorophyll concentration, and biomass production, among others $[56,58,59,127]$. This may be related to what species are used to stabilize HM, such as those referred to in Table 1. 


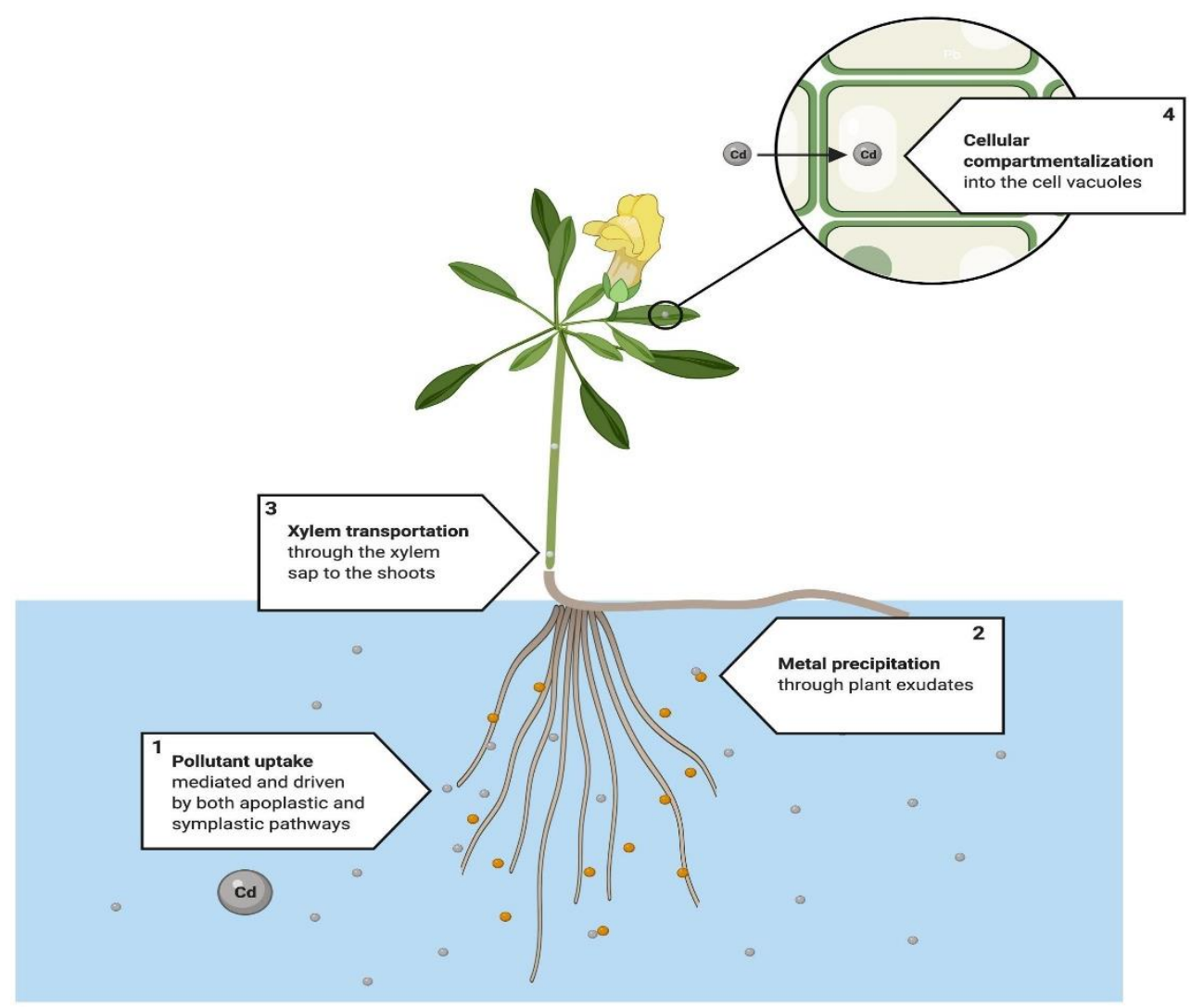

Figure 6. Proposed phytostabilization system. The main actions taken into the plant physiology are: (1) the root uptake of the metal, to start the mobilization into the plant tissues. (2) At the same time, in the areas near the roots start a precipitation process, where some beneficial bacteria may be associated with some metabolites produced by the plant's root. Finally, (3) the metals are mobilized to the aerial section, and (4) are compartmentalized in different tissues and different organelles, mainly in vacuoles, chloroplasts and sometimes mitochondrias [127-129].

\subsection{Phytovolatilization}

Phytovolatilization (Figure 7) is described as removing and fractionating pollutants within plant air spaces and later diffusion into the ambient air $[130,131]$. Thus, plants may volatilize specific metals, such as selenium [127], and volatile organic compounds (VOCs) [132]. The mechanisms that explain the mobilization of HMs are explained in Figure 7. This figure provides information on why most of the processes of the phytoremediation of HMs are focused on processes other than phytovolatilization; however, some metals, such as $\mathrm{Cd}$, may be volatilized following this process.

\subsection{Relationship Root-Microorganisms}

The relationships involving the root of plants and microorganisms are well described in soil [133]; even if an aquatic medium may modify these interactions, overall, the processes induced in rhizosphere may be similar [110,111]. In Table 2, we show a comprehensive description of the interactions in water phytoremediation where microorganisms participate, mostly plant growth-promoting rhizobacteria (PGPR). 


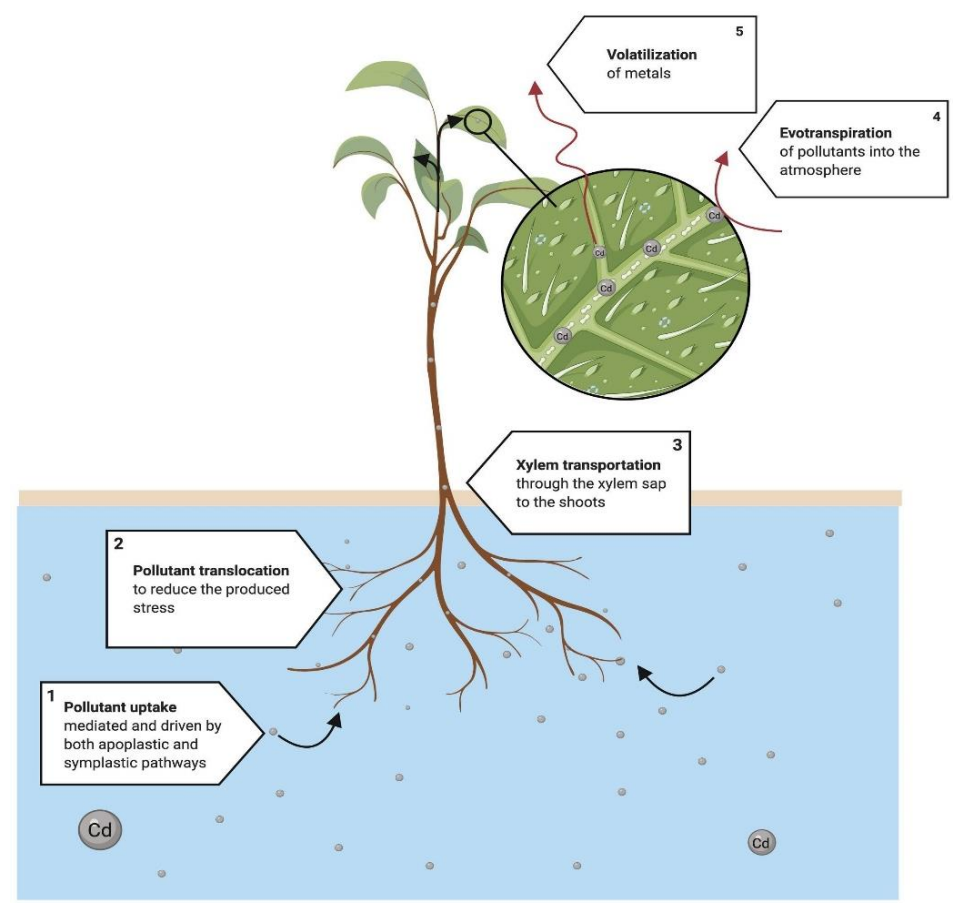

Figure 7. Proposed mechanism of phytovolatilization. (1) The process begins with the uptake and mobilization of the pollutant in the roots. (2) At the same time, the translocation of some ions, mainly metals, starts to reduce the produced stress in plant tissues. (3) The rest of the pollutants are transported to the photosynthetic area and start two main processes: (4) the evapotranspiration acts similarly to a vacuum to extract, in the presence of water, the pollutants and transport them into the atmosphere; meanwhile, (5) the combination of temperature and UV rays volatilizes the pollutants near the stomata of the leaves, mobilizing a great portion of the pollutants into the atmosphere, but transformed into less ecotoxic components/metabolites [130].

Table 2. Different processes in the root-microorganism association during phytoremediation of HMs in water.

\begin{tabular}{|c|c|c|}
\hline Microorganism & Process & Reference \\
\hline $\begin{array}{l}\text { PGPR (Paenibacillus mucilaginosus, } \\
\text { Sinorhizobium meliloti) }\end{array}$ & Increase the bioavailability of metals & [134] \\
\hline PGPR (Pseudomonas spp.) & $\begin{array}{c}\text { Increase water uptake in roots, increasing } \\
\text { HM mobilization }\end{array}$ & [135] \\
\hline PGPR (Stenotrophomonas maltophilia) & $\begin{array}{l}\text { Reduce toxicity of HMs, increasing } \\
\text { bioaccumulation factor (BF) }\end{array}$ & [136] \\
\hline PGPR (non specified) & $\begin{array}{l}\text { Transformation of HMs into less toxic } \\
\text { compounds for faster uptake }\end{array}$ & [137] \\
\hline $\begin{array}{c}\text { PGPR (Planomicrobium chinense, } \\
\text { Bacillus cereus) }\end{array}$ & $\begin{array}{c}\text { Increase biomass gain and root growth } \\
\text { during HM stress }\end{array}$ & [138] \\
\hline PGPR (Bacillus spp.) & $\begin{array}{l}\text { Reduction in oxidative stress, increasing } \\
\text { metabolite production }\end{array}$ & [139] \\
\hline Chryseobacterium sp. & $\begin{array}{l}\text { Creation of antagonistic metabolites to } \\
\text { improve resistance to pathogens }\end{array}$ & [140] \\
\hline $\begin{array}{c}\text { PGPR (Pseudomonas fluorescence, } \\
\text { Bacillus subtilis) }\end{array}$ & Increase $\mathrm{HM}$ uptake, especially $\mathrm{Pb}$ and $\mathrm{Ni}$ & [141] \\
\hline \multicolumn{3}{|c|}{$\begin{array}{l}\text { PGPR have shown positive interactions with plant roots during physiological stress, from inducing metabolite } \\
\text { production to enhancing biomass production [142], and even the way in which nutrients are recycled has similar } \\
\text { mechanisms in water and soil [110], although some processes, such as the fate of metabolites, can vary between } \\
\text { terrestrial and aquatic systems [111]. Nevertheless, dynamics on water may express different interactions and } \\
\text { may be studied in future research. }\end{array}$} \\
\hline
\end{tabular}




\subsection{Environmental Characteristics That Influence Water Phytoremediation}

The environmental characteristics of the water should be taken into account when phytoremediation systems are induced. Studies have shown the impact on different values during phytoremediation processes in water (Figure 8). For example, the iron removal capacity in some cases depends on the $\mathrm{pH}$ values, due its oxidation-reduction potential [143], and for other HMs such as $\mathrm{Zn}$ and Cd, bioavailability is directly related with higher $\mathrm{pH}$ values [144].

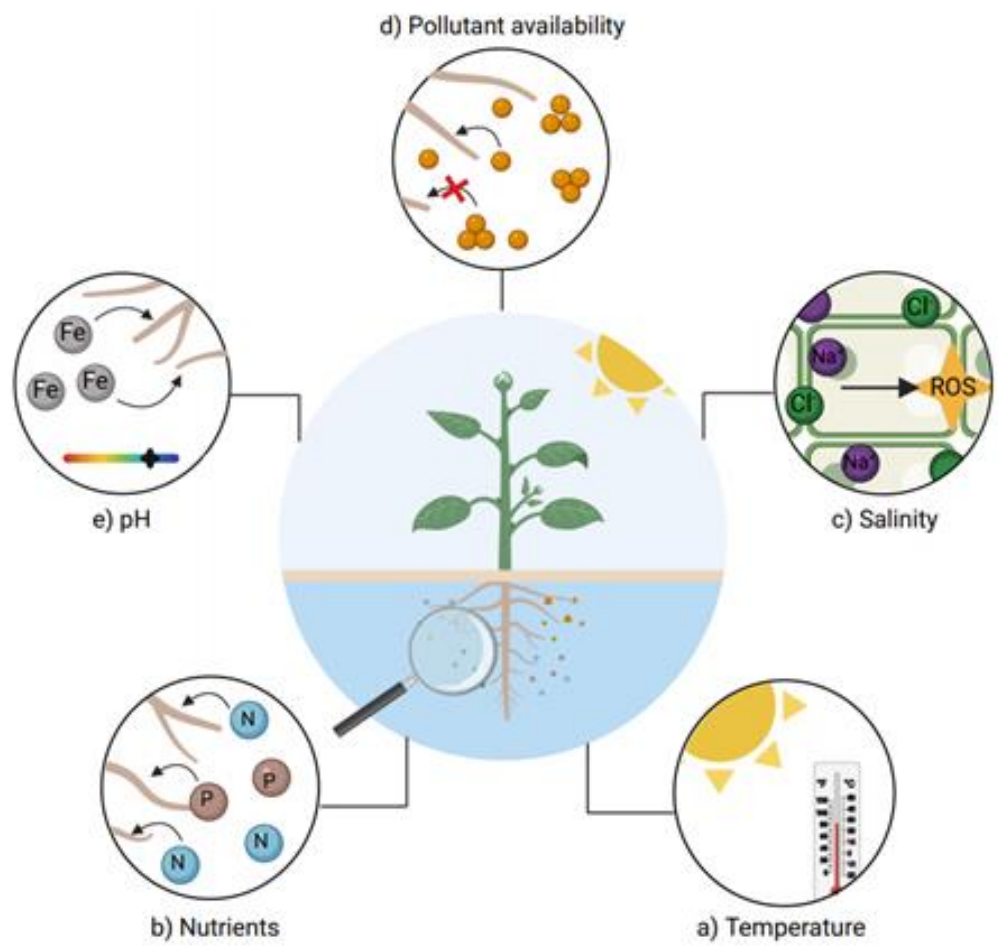

Figure 8. Main factors affecting water phytoremediation. Temperature, nutrients bioavailability, salinity, pollutant (HM) availability and $\mathrm{pH}$ are some factors that may delay phytoremediation processes. The interactions occurring in roots play an important role in systems where mobilization of the pollutant via the root is essential, such as HM phytoremediation.

On the other hand, temperature is an important factor in water phytoremediation systems, since many plant species' growth may be limited by this factor [145]. Other characteristics, such as salinity, limit the species that may be useful for the removal of HMs in water, since not every plant is halotolerant [146]; furthermore, salinity directly affects ionic homeostasis in cells and promotes the formation of reactive oxygen species (ROS) [147]. The uptake mechanisms involved in the uptake of HMs are directly related to the speed of removal [148]; the higher the bioavailability of the metals, the higher the removal speed. Finally, the nutrients absorbed through roots can accelerate or decrease the uptake of HMs. Healthy plants with the correct nutrient balance can absorb water and nutrients faster [149], thus leading to an increased uptake of HMs.

\section{Obtained Patents in the Field of Water Phytoremediation}

Patents are directly related to applied science. By describing the process and validating it, research becomes reliable and applicable worldwide. Only 9 out of the 40 reviewed species have patents related to the contaminated water treatment (Table 3). Most of the species have patents related to production, agroalimentary systems, herbal extracts, or the control of UFO species. Species such as Azolla pinnata, [140,150,151], A. pinnata, P. stratoes [152], S. polyrhiza [153], and Phragmites australis [154-156] have been registered as phytoremediators of various pollutants, and have many other usages, such as insecticides [157], low-cost supplemental food for aquaculture [158], and medical applications, 
such as antioxidant, anti-inflammatory, anti-apoptotic [159] and bioactive constituents in the extracts $[160,161]$.

Table 3. Nine species associated with the patents in phytoremediation processes or monitoring.

\begin{tabular}{|c|c|c|c|}
\hline Plant Species & Patent & Patent Number & Reference \\
\hline Azolla pinnata & Water purification system & EP0333218B1 & [162] \\
\hline Spirodela polyrhiza & $\begin{array}{l}\text { Purification method } \\
\text { of wastewater }\end{array}$ & WO2012029736A1 & [163] \\
\hline Eichhornia crassipes & $\begin{array}{c}\text { Purifying algae-type eutrophic } \\
\text { contaminated water bodies at } \\
\text { a source }\end{array}$ & CN102524084A & [164] \\
\hline Hydrilla verticillata & $\begin{array}{l}\text { The invention discloses a } \\
\text { method for removing nitrogen } \\
\text { and phosphorus in a water body }\end{array}$ & CN102311173A & [165] \\
\hline Iris pseudacorus & Waste-water purification plant & US7718062B2 & [166] \\
\hline $\begin{array}{l}\text { Myriophyllum } \\
\text { triphyllum }\end{array}$ & Marine biomass reactor & WO2018140449A1 & [167] \\
\hline Phragmites australis & $\begin{array}{l}\text { Waste treatment systems, } \\
\text { biological restoration of water } \\
\text { body, system and method for } \\
\text { removal of pollutants from water }\end{array}$ & US7361268B2 & [168] \\
\hline Potamogeton natans & $\begin{array}{l}\text { Method for repairing water } \\
\text { ecology, purifying method, } \\
\text { waste treatment process }\end{array}$ & US6652743B2 & [169] \\
\hline Pteris vittata & $\begin{array}{l}\text { Method for removing arsenic } \\
\text { from soil and water }\end{array}$ & CN105945042A & [170] \\
\hline
\end{tabular}

The patents that described the exact participation and phytoremediation processes were only those for Pteris vittata, Eichhornia crassipes, Pistia stratiotes, and Hydrilla verticillata, and most of them related to rhizofiltration and phytostabilization. The other patents referred to the processes as "plants" or just "systems" without delving into phytoremediation processes' mechanisms. There were five patents from the USA, three patents from China, and the last one out of the nine phytoremediation patents was from Japan (Figure 9, Table 3). From Table 1, we can observe that the USA and China have different studies related to phytoremediation in water, with a primary focus on hydroponic systems, to remove some organic and inorganic pollutants. There are nearly 250 reports in the last decade that infer information about phytoremediation capabilities of the reviewed species. However, the patents associated with these species barely cover nine (Figure 9), with four of them belonging to the five most representative families found in this study, which leads to an unexplored area to find and support applications for the other species. However, most of the mechanisms described in the proposed patents are limited in their application, rather than in the diversity of plants that can be used. 


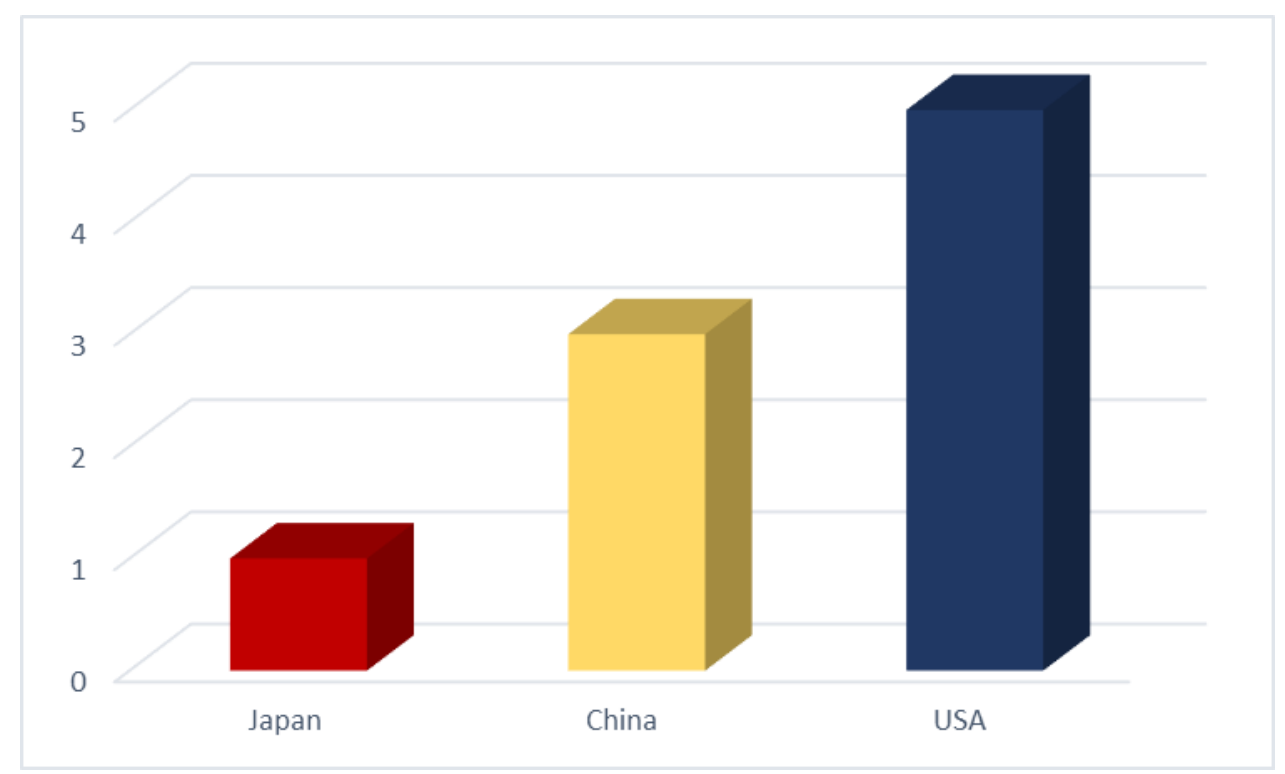

Figure 9. Only 9 patents related to water phytoremediation have been submitted, out of the 40 species that have been reported. In terms of the data collected in Table 2, the two countries with the most patents related with water phytoremediation are USA and China, followed by Japan.

\section{Current Challenges and Literature Gaps}

The unexplored field ahead, not only from genera but entire families, is a viable option to follow in current research. From all the species described as phytoremediators, just a few are associated with patents in the phytoremediation field, since water phytoremediation mechanisms have limited application. This is relevant since the data analyzed may produce more knowledge than the total registered, as described in this review, as patents are based on applied research. Another possible reason is the lack of data for each species, not only to classify them as phytoremediators but also to design an ascertainable and replicable system that can be patented. The phytoremediation processes need to be exploited to understand several in-depth variables that directly or indirectly influence bioremediation.

Another key point is selecting one species to construct a phytoremediation system. We need to consider different factors, since many contaminants do not have the same chemical structure and characteristics. This is an essential limiting factor for phytoremediation systems. The uptake mechanisms are, in several cases, affected by the microbiota coexisting near the root of the plants in soil and water systems. One main reason for the low uptake and mobilization of the contaminants is the root cells' lack of capacity to capture the compound. The last key point to highlight is the limitation of the contaminant uptake, mediated by the water's physicochemical conditions, such as $\mathrm{pH}$, electric conductivity, and cation exchange capacity, among others. These factors can be modified or regulated to improve and accelerate the ecotoxic compound's mobilization, which needs to be treated.

The solution to each key point is as vast as the total number of plant species around the world. Every species, and even each individual, has a wide variety of strategies to mobilize certain compounds, including ecotoxic. Suppose one contaminant remains immovable from the substrate or sediments in the water. In that case, the combination of different plant species may help in different ways, from breaking chemical bonds to volatilizing the entire compound or even reducing the bioavailability to other organisms. Describing exact processes in water phytoremediation systems may help to provide new ways to understand phytoremediation. However, there is a dire need to emphasize the importance of exploring species, genera, and entire families' phytoremediation capabilities. We need to address pollution issues from a sustainable and interdisciplinary perspective. Current data show that the cost-benefit of phytoremediation may be higher than traditional treatments, such as chemical or physical. The infrastructure of many countries can not apply efficient 
conventional techniques. From this perspective, phytoremediation is a viable strategy to solve many countries' water issues, meaning that it is an essential and urgent topic for research.

\section{Conclusions}

Water pollution is an issue that needs to be addressed from an ecologically friendly perspective, since many diseases are directly related to polluted drinking water. Phytoremediation opens up opportunities aiding in the removal of contaminants that may be hazardous to many organisms. There are a wide range of strategies and mechanisms described in phytoremediation, and there is more experimental information in soil than water. However, the application of these systems may remain uncertain. On one hand, the related data showed the lack of information associated with many plant species compared with the total species in general. This is an important issue, since many plant species from the same genera showed phytoremediation capabilities.

From the 40 species reviewed in total, the wide variety of phytoremediators grow naturally into or along areas associated with water bodies. This is a necessary trait to consider, since the uptake mechanisms of terrestrial and aquatic plants may differ; however, the literature showed that the association between microorganisms and root may not be limited in water systems. Nevertheless, the overall phytoremediation system can explain the uptake and mobilization dynamics of the contaminant without considering this factor. By comparing the results, we can address many factors that limit the analysis, such as the results presented in different measurement units. Even though the conversion of units can be applied, the methodology described in various studies might add some noise effects, since the reactive conditions, time of observation, and many other variables are not equal. Different species behave differently towards each contaminant. Even if one species shows positive results in removing specific pollutants, it might not be useful for other types of compounds.

The more studies that address the importance of biodiversity in terms of water HM phytoremediation, the more possibilities can be explored to provide and explain precise mechanisms for HM removal in water, using different species of plants to expand the proposed systems and the associated patents.

Author Contributions: Conceptualization, A.S.; methodology, A.S., A.M.-N. and C.R.D.-G.; validation, A.S., A.M.-N., G.O. and H.M.N.I.; formal analysis, M.I.-P., C.R.D.-G. and J.M.F.-C.; investigation, M.I.-P., C.R.D.-G. and J.M.F.-C.; writing—original draft preparation, C.R.D.-G. and J.M.F.-C.; writingreview and editing C.R.D.-G., J.M.F.-C., A.S. and A.M.-N.; supervision, A.S. All authors have read and agreed to the published version of the manuscript.

Funding: This research received no external funding.

Institutional Review Board Statement: Not applicable.

Informed Consent Statement: Not applicable.

Data Availability Statement: All the references included in this review has their corresponding citation for further discussion and analysis.

Acknowledgments: This research did not receive any specific grant from funding agencies in the public, commercial, or not-for-profit sectors. The authors acknowledge the page BioRender.com as the main program used to make the Figures 2-8 presented in this review. Corresponding author owns a License of Biorender.com for their publication.

Conflicts of Interest: The authors declare no conflict of interest. 


\section{References}

1. World Health Organization. Drinking Water. 2020. Available online: https://www.who.int/news-room/fact-sheets/detail/ drinking-water\#: \{\}:text=Contaminated $\% 20$ water $\% 20$ and $\% 20$ poor $\% 20$ sanitation, A $\% 2 \mathrm{C} \% 20$ typhoid $\% 2 \mathrm{C} \% 20 \mathrm{and} \% 20$ polio (accessed on 16 November 2020).

2. Chen, L.; Zhou, S.; Shi, Y.; Wang, C.; Li, B.; Li, Y.; Wu, S. Heavy metals in food crops, soil, and water in the Lihe River Watershed of the Taihu Region and their potential health risks when ingested. Sci. Total Environ. 2018, 615, 141-149. [CrossRef]

3. Bamuwamye, M.; Ogwok, P.; Tumuhairwe, V.; Eragu, R.; Nakisozi, H.; Ogwang, P.E. Human health risk assessment of heavy metals in Kampala (Uganda) drinking water. J. Food Res. 2017, 6, 6-16. [CrossRef]

4. Ashraf, N.; Glaeser, E.; Holland, A.; Steinberg, B.M. Water, Health and Wealth; Working Paper 23807; National Bureau of Economic Research: Cambridge, MA, USA, 2017.

5. Su, F.; Wu, J.; He, S. Set pair analysis-Markov chain model for groundwater quality assessment and prediction: A case study of Xi'an city, China. Hum. Ecol. Risk Assess. Int. J. 2019, 25, 158-175. [CrossRef]

6. Li, P.; Wu, J. Drinking Water Quality and Public Health. Expo. Health 2019, 11, 73-79. [CrossRef]

7. Scheili, A.; Rodriguez, M.; Sadiq, R. Seasonal and spatial variations of source and drinking water quality in small municipal systems of two Canadian regions. Sci. Total Environ. 2015, 508, 514-524. [CrossRef] [PubMed]

8. Karthigadevi, G.; Manikandan, S.; Karmegam, N.; Subbaiya, R.; Chozhavendhan, S.; Balasubramani, R.; Chang, S.W.; Awasthi, M.K. Chemico-nanotreatment methods for the removal of persistent organic pollutants and xenobiotics in water-A review. Bioresour. Technol. 2021, 324, 124678. [CrossRef] [PubMed]

9. Pi, Y.; Li, X.; Xia, Q.; Wu, J.; Li, Y.; Xiao, J.; Li, Z. Adsorptive and photocatalytic removal of Persistent Organic Pollutants (POPs) in water by metal-organic frameworks (MOFs). Chem. Eng. J. 2018, 337, 351-371. [CrossRef]

10. Abdel-Satar, A.M.; Ali, M.H.; Goher, M.E. Indices of water quality and metal pollution of Nile River, Egypt. Egypt. J. Aquat. Res. 2017, 43, 21-29. [CrossRef]

11. Anh, H.Q.; Le, T.P.Q.; Da Le, N.; Lu, X.X.; Duong, T.T.; Garnier, J.; Rochelle-Newall, E.; Zhang, S.; Oh, N.-H.; Oeurng, C.; et al. Antibiotics in surface water of East and Southeast Asian countries: A focused review on contamination status, pollution sources, potential risks, and future perspectives. Sci. Total Environ. 2021, 764, 142865. [CrossRef]

12. Chowdhary, P.; Raj, A.; Bharagava, R.N. Environmental pollution and health hazards from distillery wastewater and treatment approaches to combat the environmental threats: A review. Chemosphere 2018, 194, 229-246. [CrossRef]

13. Dwivedi, S.; Mishra, S.; Tripathi, R.D. Ganga water pollution: A potential health threat to inhabitants of Ganga basin. Environ. Int. 2018, 117, 327-338. [CrossRef] [PubMed]

14. Kumar, V.; Parihar, R.D.; Sharma, A.; Bakshi, P.; Sidhu, G.P.S.; Bali, A.S.; Karaouzas, I.; Bhardwaj, R.; Thukral, A.K.; Gyasi-Agyei, Y.; et al. Global evaluation of heavy metal content in surface water bodies: A meta-analysis using heavy metal pollution indices and multivariate statistical analyses. Chemosphere 2019, 236, 124364. [CrossRef]

15. Li, X.; Wang, B.; Cao, Y.; Zhao, S.; Wang, H.; Feng, X.; Zhou, J.; Ma, X. Water Contaminant Elimination Based on Metal-Organic Frameworks and Perspective on Their Industrial Applications. ACS Sustain. Chem. Eng. 2019, 7, 4548-4563. [CrossRef]

16. Mohiuddin, A.K. Chemical Contaminants and Pollutants in the Measurable Life of Dhaka City. Eur. J. Sustain. Dev. Res. 2019, 3, em0083. [CrossRef]

17. Ustaoğlu, F.; Tepe, Y. Water quality and sediment contamination assessment of Pazarsuyu Stream, Turkey using multivariate statistical methods and pollution indicators. Int. Soil Water Conserv. Res. 2019, 7, 47-56. [CrossRef]

18. Al Osman, M.; Yang, F.; Massey, I.Y. Exposure routes and health effects of heavy metals on children. BioMetals 2019, 32, 563-573. [CrossRef]

19. Fu, Z.; Xi, S. The effects of heavy metals on human metabolism. Toxicol. Mech. Methods 2019, 30, 167-176. [CrossRef] [PubMed]

20. Sankhla, M.S.; Kumar, R. Contaminant of Heavy Metals in Groundwater \& its Toxic Effects on Human Health \& Environment. SSRN Electron. J. 2019. [CrossRef]

21. Tangahu, B.V.; Abdullah, S.R.S.; Basri, H.; Idris, M.; Anuar, N.; Mukhlisin, M. A Review on Heavy Metals (As, Pb, and Hg) Uptake by Plants through Phytoremediation. Int. J. Chem. Eng. 2011, 2011, 939161. [CrossRef]

22. EPA (United States Environmental Protection Agency). EnviroAtlas. Heavy Metals. 2020. Available online: https://cfpub.epa. gov/ncea/iris2/chemicalLanding.cfm?substance_nmbr=278\&layout=option1 (accessed on 16 November 2020).

23. Kim, K.-H.; Kabir, E.; Jahan, S.A. Exposure to pesticides and the associated human health effects. Sci. Total Environ. 2017, 575, 525-535. [CrossRef]

24. Hua, M.; Zhang, S.; Pan, B.; Zhang, W.; Lv, L.; Zhang, Q. Heavy metal removal from water/wastewater by nanosized metal oxides: A review. J. Hazard. Mat. 2012, 211, 317-331. [CrossRef] [PubMed]

25. Heltshe, J.F.; Forrester, N.E. Estimating species richness using the jackknife procedure. Biometrics 1983, 39, 1-11. [CrossRef]

26. Zeng, X.; Xia, Y.; Tong, H. Jackknife approach to the estimation of mutual information. Proc. Natl. Acad. Sci. USA 2018, 115, 9956-9961. [CrossRef] [PubMed]

27. Bokhari, S.H.; Ahmad, I.; Mahmood-Ul-Hassan, M.; Mohammad, A. Phytoremediation potential of Lemna minor L. for heavy metals. Int. J. Phytoremediat. 2015, 18, 25-32. [CrossRef] [PubMed]

28. Tauqeer, H.M.; Ali, S.; Rizwan, M.; Ali, Q.; Saeed, R.; Iftikhar, U.; Ahmad, R.; Farid, M.; Abbasi, G.H. Phytoremediation of heavy metals by Alternanthera bettzickiana: Growth and physiological response. Ecotoxicol. Environ. Saf. 2016, 126, 138-146. [CrossRef] 
29. Nayak, A.K.; Panda, S.S.; Basu, A.; Dhal, N.K. Enhancement of toxic Cr (VI), Fe, and other heavy metals phytoremediation by the synergistic combination of native Bacillus cereus strain and Vetiveria zizanioides L. Int. J. Phytoremediat. 2018, 20, 682-691. [CrossRef]

30. Zhang, X.; Li, M.; Yang, H.; Li, X.; Cui, Z. Physiological responses of Suaeda glauca and Arabidopsis thaliana in phytoremediation of heavy metals. J. Environ. Manag. 2018, 223, 132-139. [CrossRef] [PubMed]

31. Adler, P.R.; Summerfelt, S.T.; Glenn, D.; Takeda, F. Mechanistic approach to phytoremediation of water. Ecol. Eng. 2003, 20, 251-264. [CrossRef]

32. Bolisetty, S.; Peydayesh, M.; Mezzenga, R. Sustainable technologies for water purification from heavy metals: Review and analysis. Chem. Soc. Rev. 2019, 48, 463-487. [CrossRef] [PubMed]

33. Joseph, L.; Jun, B.M.; Flora, J.R.; Park, C.M.; Yoon, Y. Removal of heavy metals from water sources in the developing world using low-cost materials: A review. Chemosphere 2019, 229, 142-159. [CrossRef]

34. Muthusaravanan, S.; Sivarajasekar, N.; Vivek, J.S.; Paramasivan, T.; Naushad, M.; Prakashmaran, J.; Gayathri, V.; Al-Duaij, O.K. Phytoremediation of heavy metals: Mechanisms, methods and enhancements. Environ. Chem. Lett. 2018, 16, 1339-1359. [CrossRef]

35. Mirza, N.; Mahmood, Q.; Pervez, A.; Ahmad, R.; Farooq, R.; Shah, M.M.; Azim, M.R. Phytoremediation potential of Arundo donax in arsenic-contaminated synthetic wastewater. Bioresour. Technol. 2010, 101, 5815-5819. [CrossRef] [PubMed]

36. Pandey, V.C. Phytoremediation of heavy metals from fly ash pond by Azolla caroliniana. Ecotoxicol. Environ. Saf. 2012, 82, 8-12. [CrossRef] [PubMed]

37. Benaroya, R.O.; Tzin, V.; Tel-Or, E.; Zamski, E. Lead accumulation in the aquatic fern Azolla filiculoides. Plant Physiol. Biochem. 2004, 42, 639-645. [CrossRef] [PubMed]

38. Valderrama, A.; Tapia, J.; Peñailillo, P.; Carvajal, D.E. Water phytoremediation of cadmium and copper using Azolla filiculoides Lam. in a hydroponic system. Water Environ. J. 2012, 27, 293-300. [CrossRef]

39. Rai, P.K. Technical Note: Phytoremediation of $\mathrm{Hg}$ and $\mathrm{Cd}$ from Industrial Effluents using an Aquatic Free Floating Macrophyte Azolla pinnata. Int. J. Phytoremediat. 2008, 10, 430-439. [CrossRef]

40. Khandare, R.V.; Watharkar, A.D.; Pawar, P.K.; Jagtap, A.A.; Desai, N.S. Hydrophytic plants Canna indica, Epipremnum aureum, Cyperus alternifolius and Cyperus rotundus for phytoremediation of fluoride from water. Environ. Technol. Innov. 2021, 21, 101234. [CrossRef]

41. Abdallah, M.A.M. Phytoremediation of heavy metals from aqueous solutions by two aquatic macrophytes, Ceratophyllum demersum and Lemna gibba L. Environ. Technol. 2012, 33, 1609-1614. [CrossRef]

42. Ingole, N.W.; Bhole, A.G. Removal of heavy metals from aqueous solution by water hyacinth (Eichhornia crassipes). J. Water Supply Res. Technol. 2003, 52, 119-128. [CrossRef]

43. Odjegba, V.J.; Fasidi, I.O. Phytoremediation of heavy metals by Eichhornia crassipes. Environmentalist 2007, 27, 349-355. [CrossRef]

44. Sakakibara, M.; Ohmori, Y.; Ha, N.T.H.; Sano, S.; Sera, K. Phytoremediation of heavy metal-contaminated water and sediment by Eleocharis acicularis. Clean Soil Air Water 2011, 39, 735-741. [CrossRef]

45. Mukhtar, S.A.I.M.A.; Bhatti, H.N.; Khalid, M.; Haq, M.A.U.; Shahzad, S.M. Potential of sunflower (Helianthus annuus L.) for phytoremediation of nickel (Ni) and lead $(\mathrm{Pb})$ contaminated water. Pak. J. Bot. 2010, 42, 4017-4026.

46. Dixit, S.; Dhote, S. Evaluation of uptake rate of heavy metals by Eichhornia crassipes and Hydrilla verticillata. Environ. Monit. Assess. 2009, 169, 367-374. [CrossRef] [PubMed]

47. Sinha, S.; Saxena, R.; Singh, S. Fluoride Removal from Water by Hydrilla verticillata (l.f.) Royle and Its Toxic Effects. Bull. Environ. Contam. Toxicol. 2000, 65, 683-690. [CrossRef]

48. Xue, P.-Y.; Yan, C.-Z. Arsenic accumulation and translocation in the submerged macrophyte Hydrilla verticillata (L.f.) Royle. Chemosphere 2011, 85, 1176-1181. [CrossRef]

49. Chanu, L.B.; Gupta, A. Phytoremediation of lead using Ipomoea aquatica Forsk. in hydroponic solution. Chemosphere 2016, 156, 407-411. [CrossRef] [PubMed]

50. Weerasinghe, A.; Ariyawnasa, S.; Weerasooriya, R. Phyto-remediation potential of Ipomoea aquatica for Cr(VI) mitigation. Chemosphere 2008, 70, 521-524. [CrossRef] [PubMed]

51. Caldelas, C.; Araus, J.L.; Febrero, A.; Bort, J. Accumulation and toxic effects of chromium and zinc in Iris pseudacorus L. Acta Physiol. Plant. 2012, 34, 1217-1228. [CrossRef]

52. Najeeb, U.; Ahmad, W.; Zia, M.H.; Zaffar, M.; Zhou, W. Enhancing the lead phytostabilization in wetland plant Juncus effusus L. through somaclonal manipulation and EDTA enrichment. Arab. J. Chem. 2017, 10, S3310-S3317. [CrossRef]

53. Mkandawire, M.; Taubert, B.; Dudel, E.G. Capacity of Lemna gibba L. (Duckweed) for Uranium and Arsenic Phytoremediation in Mine Tailing Waters. Int. J. Phytoremediat. 2004, 6, 347-362. [CrossRef]

54. Wang, Q.; Cui, Y.; Dong, Y. Phytoremediation of Polluted Waters Potentials and Prospects of Wetland Plants. Acta Biotechnol. 2002, 22, 199-208. [CrossRef]

55. Vernay, P.; Gauthier-Moussard, C.; Hitmi, A. Interaction of bioaccumulation of heavy metal chromium with water relation, mineral nutrition and photosynthesis in developed leaves of Lolium perenne L. Chemosphere 2007, 68, 1563-1575. [CrossRef] [PubMed]

56. Galal, T.M.; Al-Sodany, Y.M.; Al-Yasi, H.M. Phytostabilization as a phytoremediation strategy for mitigating water pollutants by the floating macrophyte Ludwigia stolonifera (Guill. \& Perr.) P.H. Raven. Int. J. Phytoremediat. 2019, 22, 373-382. [CrossRef]

57. Zurayk, R.; Sukkariyah, B.; Baalbaki, R.; Ghanem, D.A. Ni Phytoaccumulation in Mentha aquatica L. and Mentha sylvestris L. Water Air Soil Pollut. 2002, 139, 355-364. [CrossRef] 
58. Colzi, I.; Lastrucci, L.; Rangoni, M.; Coppi, A.; Gonnelli, C. Using Myriophyllum aquaticum (Vell.) Verdc. to remove heavy metals from contaminated water: Better dead or alive? J. Environ. Manag. 2018, 213, 320-328. [CrossRef]

59. Sivaci, E.R.; Sivaci, A.; Sökmen, M. Biosorption of cadmium by Myriophyllum spicatum L. and Myriophyllum triphyllum orchard. Chemosphere 2004, 56, 1043-1048. [CrossRef]

60. Xia, J.; Hua, T.; Xue, Y.; Zhao, L.; Sun, H.; Liu, C. Myriophyllum elatinoides: A potential candidate for the phytoremediation of water with low level boron contamination. J. Hazard. Mater. 2021, 401, 123333. [CrossRef]

61. Kumar, J.N.; Soni, H.; Kumar, R.N.; Bhatt, I. Macrophytes in phytoremediation of heavy metal contaminated water and sediments in Pariyej Community Reserve, Gujarat, India. Turk. J. Fish. Aquat. Sci. 2008, 8, 193-200.

62. Cheng, S. Heavy metals in plants and phytoremediation. Environ. Sci. Pollut. Res. 2003, 10, 335-340. [CrossRef]

63. Bello, A.O.; Tawabini, B.S.; Khalil, A.B.; Boland, C.R.; Saleh, T.A. Phytoremediation of cadmium-, lead- and nickel-contaminated water by Phragmites australis in hydroponic systems. Ecol. Eng. 2018, 120, 126-133. [CrossRef]

64. Das, S.; Goswami, S.; Das Talukdar, A. A Study on Cadmium Phytoremediation Potential of Water Lettuce, Pistia stratiotes L. Bull. Environ. Contam. Toxicol. 2013, 92, 169-174. [CrossRef]

65. Kumar, V.; Singh, J.; Saini, A.; Kumar, P. Phytoremediation of copper, iron and mercury from aqueous solution by water lettuce (Pistia stratiotes L.). Environ. Sustain. 2019, 2, 55-65. [CrossRef]

66. Romeh, A.A. Phytoremediation of cyanophos insecticide by Plantago major L. in water. J. Environ. Health Sci. Eng. 2014, 12, 38. [CrossRef] [PubMed]

67. Fritioff, Å.; Greger, M. Uptake and distribution of $\mathrm{Zn}, \mathrm{Cu}, \mathrm{Cd}$, and $\mathrm{Pb}$ in an aquatic plant Potamogeton natans. Chemosphere 2006, 63, 220-227. [CrossRef] [PubMed]

68. Huang, Z.C.; Chen, T.B.; Lei, M.; Hu, T.D. Direct determination of arsenic species in arsenic hyperaccumulator Pteris vittata by EXAFS. Acta Bot. 2004, 46, 46-50.

69. Loría, K.C.; Emiliani, J.; Bergara, C.D.; Herrero, M.S.; Salvatierra, L.M.; Pérez, L.M. Effect of daily exposure to Pb-contaminated water on Salvinia biloba physiology and phytoremediation performance. Aquat. Toxicol. 2019, 210, 158-166. [CrossRef]

70. Hoffmann, T.L.; Kutter, C.; Santamaria, J.M. Capacity of Salvinia minima Baker to Tolerate and Accumulate As and Pb. Eng. Life Sci. 2004, 4, 61-65. [CrossRef]

71. Da Silva, A.A.; De Oliveira, J.A.; De Campos, F.V.; Ribeiro, C.; Farnese, F.D.S.; Costa, A.C. Phytoremediation potential of Salvinia molesta for arsenite contaminated water: Role of antioxidant enzymes. Theor. Exp. Plant Physiol. 2018, 30, 275-286. [CrossRef]

72. Dhir, B.; Srivastava, S. Heavy metal removal from a multi-metal solution and wastewater by Salvinia natans. Ecol. Eng. 2011, 37, 893-896. [CrossRef]

73. Rahman, M.A.; Hasegawa, H.; Ueda, K.; Maki, T.; Okumura, C. Arsenic accumulation in duckweed (Spirodela polyrhiza L.): A good option for phytoremediation. Chemosphere 2007, 69, 493-499. [CrossRef]

74. Kumar, V.; Chopra, A.K. Phytoremediation potential of water caltrop (Trapa natans L.) using municipal wastewater of the activated sludge process-based municipal wastewater treatment plant. Environ. Technol. 2018, 39, 12-23. [CrossRef] [PubMed]

75. Eid, E.M.; Shaltout, K.H.; El-Sheikh, M.A.; Asaeda, T. Seasonal courses of nutrients and heavy metals in water, sediment and above- and below-ground Typha domingensis biomass in Lake Burullus (Egypt): Perspectives for phytoremediation. Flora 2012, 207, 783-794. [CrossRef]

76. Gomes, M.V.T.; de Souza, R.R.; Teles, V.S.; Mendes, É.A. Phytoremediation of water contaminated with mercury using Typha domingensis in constructed wetland. Chemosphere 2014, 103, 228-233. [CrossRef]

77. Hejna, M.; Moscatelli, A.; Stroppa, N.; Onelli, E.; Pilu, S.; Baldi, A.; Rossi, L. Bioaccumulation of heavy metals from wastewater through a Typha latifolia and Thelypteris palustris phytoremediation system. Chemosphere 2020, 241, 125018. [CrossRef]

78. Li, B.; Gu, B.; Yang, Z.; Zhang, T. The role of submerged macrophytes in phytoremediation of arsenic from contaminated water: A case study on Vallisneria natans (Lour.) Hara. Ecotoxicol. Environ. Saf. 2018, 165, 224-231. [CrossRef]

79. Boonyapookana, B.; Upatham, E.S.; Kruatrachue, M.; Pokethitiyook, P.; Singhakaew, S. Phytoaccumulation and Phytotoxicity of Cadmium and Chromium in Duckweed Wolffia globosa. Int. J. Phytoremediat. 2002, 4, 87-100. [CrossRef] [PubMed]

80. Zhang, X.; Zhao, F.; Huang, Q.; Williams, P.N.; Sun, G.; Zhu, Y. Arsenic uptake and speciation in the rootless duckweed Wolffia globosa. New Phytol. 2009, 182, 421-428. [CrossRef]

81. Datta, S.; Rajnish, K.N.; Samuel, M.S.; Pugazlendhi, A.; Selvarajan, E. Metagenomic applications in microbial diversity, bioremediation, pollution monitoring, enzyme and drug discovery. A review. Environ. Chem. Lett. 2020, 18, 1229-1241. [CrossRef]

82. Gałązka, A.; Grządziel, J.; Gałązka, R.; Gawryjołek, K.; Ukalska-Jaruga, A.; Smreczak, B. Fungal Community, Metabolic Diversity, and Glomalin-Related Soil Proteins (GRSP) Content in Soil Contaminated with Crude Oil after Long-Term Natural Bioremediation. Front. Microbiol. 2020, 11, 2247. [CrossRef]

83. Camacho-Montealegre, C.M.; Rodrigues, E.M.; Tótola, M.R. Microbial diversity and bioremediation of rhizospheric soils from Trindade Island-Brazil. J. Environ. Manag. 2019, 236, 358-364. [CrossRef]

84. Christenhusz, M.J.; Byng, J.W. The number of known plants species in the world and its annual increase. Phytotaxa 2016, 261, 201-217. [CrossRef]

85. Schneller, J.J. Salviniaceae. In Pteridophytes and Gymnosperms; Springer: Berlin/Heidelberg, Germany, 1990; pp. 256-258.

86. Arana, M.D. Familia SALVINIACEAE Martinov; Dykinson: Madrid, Spain, 2016; pp. 343-348. 
87. Cusimano, N.; Bogner, J.; Mayo, S.J.; Boyce, P.C.; Wong, S.Y.; Hesse, M.; Hetterscheid, W.L.A.; Keating, R.C.; French, J.C. Relationships within the Araceae: Comparison of morphological patterns with molecular phylogenies. Am. J. Bot. 2011, 98, 654-668. [CrossRef] [PubMed]

88. Goetghebeur, P. Cyperaceae. In Flowering Plants Monocotyledons; Springer: Berlin/Heidelberg, Germany, 1998; pp. 141-190. [CrossRef]

89. Saarela, J.M.; Burke, S.V.; Wysocki, W.P.; Barrett, M.D.; Clark, L.G.; Craine, J.M.; Peterson, P.M.; Soreng, R.J.; Vorontsova, M.S.; Duvall, M.R. A 250 plastome phylogeny of the grass family (Poaceae): Topological support under different data partitions. PeerJ 2018, 6, e4299. [CrossRef] [PubMed]

90. Schweingruber, F.H.; Kučerová, A.; Adamec, L.; Doležal, J. Haloragaceae. In Anatomic Atlas of Aquatic and Wetland Plant Stems; Springer: Cham, Switzerland, 2020; pp. 139-142. [CrossRef]

91. Semmouri, I.; Bauters, K.; Léveillé-Bourret, É.; Starr, J.R.; Goetghebeur, P.; Larridon, I. Phylogeny and Systematics of Cyperaceae, the Evolution and Importance of Embryo Morphology. Bot. Rev. 2018, 85, 1-39. [CrossRef]

92. Chen, Z.; Cuervo, D.P.; Müller, J.A.; Wiessner, A.; Köser, H.; Vymazal, J.; Kästner, M.; Kuschk, P. Hydroponic root mats for wastewater treatment-A review. Environ. Sci. Pollut. Res. 2016, 23, 15911-15928. [CrossRef] [PubMed]

93. Mathieu, L.; Lobet, G.; Tocquin, P.; Périlleux, C. "Rhizoponics": A novel hydroponic rhizotron for root system analyses on mature Arabidopsis thaliana plants. Plant Methods 2015, 11, 1-8. [CrossRef]

94. Cheng, S.; Grosse, W.; Karrenbrock, F.; Thoennessen, M. Efficiency of constructed wetlands in decontamination of water polluted by heavy metals. Ecol. Eng. 2002, 18, 317-325. [CrossRef]

95. Vymazal, J.; Březinová, T. Accumulation of heavy metals in aboveground biomass of Phragmites australis in horizontal flow constructed wetlands for wastewater treatment: A review. Chem. Eng. J. 2016, 290, 232-242. [CrossRef]

96. Almasi, A.; Dargahi, A.; Ahagh, M.; Janjani, H.; Mohammadi, M.; Tabandeh, L. Efficiency of a constructed wetland in controlling organic pollutants, nitrogen, and heavy metals from sewage. J. Chem. Pharm. Sci. 2016, 9, 2924-2928.

97. Horne, A.J. Phytoremediation by constructed wetlands. In Phytoremediation of Contaminated Soil and Water; CRC Press: Boca Raton, FL, USA, 2000.

98. Guittonny-Philippe, A.; Petit, M.E.; Masotti, V.; Monnier, Y.; Malleret, L.; Coulomb, B.; Laffont-Schwob, I. Selection of wild macrophytes for use in constructed wetlands for phytoremediation of contaminant mixtures. J. Environ. Manag. 2015, 147, 108-123. [CrossRef]

99. Salt, D.E.; Smith, R.D.; Raskin, I. Phytoremediation. Annu. Rev. Plant Biol. 1998, 49, 643-668. [CrossRef] [PubMed]

100. Chaney, R.L.; Malik, M.; Li, Y.M.; Brown, S.L.; Brewer, E.P.; Angle, J.S.; Baker, A.J. Phytoremediation of soil metals. Curr. Opin. Biotechnol. 1997, 8, 279-284. [CrossRef]

101. Flathman, P.E.; Lanza, G.R. Phytoremediation: Current Views on an Emerging Green Technology. Soil Sediment Contam. Int. J. 1998, 7, 415-432. [CrossRef]

102. Peuke, A.D.; Rennenberg, H. Phytoremediation. EMBO Rep. 2005, 6, 497-501. [CrossRef] [PubMed]

103. Pilon-Smits, E. Phytoremediation. Annu. Rev. Plant Biol. 2005, 56, 15-39. [CrossRef]

104. Yang, X.; Feng, Y.; He, Z.; Stoffella, P.J. Molecular mechanisms of heavy metal hyperaccumulation and phytoremediation. J. Trace Elem. Med. Biol. 2005, 18, 339-353. [CrossRef] [PubMed]

105. Jabeen, R.; Ahmad, A.; Iqbal, M.F. Phytoremediation of Heavy Metals: Physiological and Molecular Mechanisms. Bot. Rev. 2009, 75, 339-364. [CrossRef]

106. Ali, H.; Khan, E.; Sajad, M.A. Phytoremediation of heavy metals-Concepts and applications. Chemosphere 2013, 91, 869-881. [CrossRef]

107. Suman, J.; Uhlik, O.; Viktorova, J.; Macek, T. Phytoextraction of Heavy Metals: A Promising Tool for Clean-Up of Polluted Environment? Front. Plant Sci. 2018, 9, 1476. [CrossRef]

108. Lombi, E.; Tearall, K.L.; Howarth, J.R.; Zhao, F.-J.; Hawkesford, M.J.; McGrath, S.P. Influence of Iron Status on Cadmium and Zinc Uptake by Different Ecotypes of the Hyperaccumulator Thlaspi caerulescens. Plant Physiol. 2002, 128, 1359-1367. [CrossRef]

109. Whiting, S.N.; De Souza, A.M.P.; Terry, N. Rhizosphere Bacteria Mobilize Zn for Hyperaccumulation by Thlaspicaerulescens. Environ. Sci. Technol. 2001, 35, 3144-3150. [CrossRef] [PubMed]

110. Flores, H. 'Radicle' biochemistry: The biology of root-specific metabolism. Trends Plant Sci. 1999, 4, 220-226. [CrossRef]

111. Lin, Y.P.; Lin, C.M.; Mukhtar, H.; Lo, H.F.; Ko, M.C.; Wang, S.J. Temporal Variability in the Rhizosphere Bacterial and Fungal Community Structure in the Melon Crop Grown in a Closed Hydroponic System. Agronomy 2021, 11, 719. [CrossRef]

112. Sheridan, C.; Depuydt, P.; De Ro, M.; Petit, C.; Van Gysegem, E.; Delaere, P.; Dixon, M.; Stasiak, M.; Aciksöz, S.B.; Frossard, E.; et al. Microbial Community Dynamics and Response to Plant Growth-Promoting Microorganisms in the Rhizosphere of Four Common Food Crops Cultivated in Hydroponics. Microb. Ecol. 2016, 73, 378-393. [CrossRef]

113. Clarkson, D.T. Roots and the delivery of solutes to the xylem. Philos. Trans. R. Soc. B Biol. Sci. 1993, 341, 5-17. [CrossRef]

114. Tester, M.; Leigh, R.A. Partitioning of nutrient transport processes in roots. J. Exp. Bot. 2001, 52, 445-457. [CrossRef]

115. Cobbett, C.; Goldsbrough, P. Phytochelatins and metallothioneins: Roles in Heavy Metal Detoxification and Homeostasis. Annu. Rev. Plant Biol. 2002, 53, 159-182. [CrossRef] [PubMed]

116. Dushenkov, V.; Kumar, P.B.A.N.; Motto, H.; Raskin, I. Rhizofiltration: The Use of Plants to Remove Heavy Metals from Aqueous Streams. Environ. Sci. Technol. 1995, 29, 1239-1245. [CrossRef] 
117. Burken, J.G. Uptake and Metabolism of Organic Compounds: Green-Liver Model. Phytoremediat. Transform. Control Contam. 2004, 59, 59-84. [CrossRef]

118. Garrison, A.W.; Nzengung, V.A.; Avants, J.K.; Ellington, J.J.; Jones, W.J.; Rennels, D.; Wolfe, N.L. Phytodegradation of p, p'-DDT

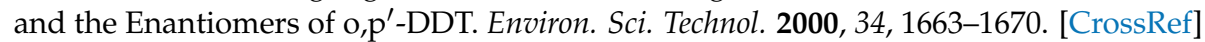

119. Newman, L.A.; Reynolds, C.M. Phytodegradation of organic compounds. Curr. Opin. Biotechnol. 2004, 15, 225-230. [CrossRef] [PubMed]

120. McCutcheon, S.C.; Schnoor, J.L. Overview of phytotransformation and control of wastes. In Phytoremediation: Transformation and Control of Contaminants; Wiley: New York, NY, USA, 2003; pp. 1-58. [CrossRef]

121. Kuiper, I.; Lagendijk, E.L.; Bloemberg, G.V.; Lugtenberg, B.J.J. Rhizoremediation: A Beneficial Plant-Microbe Interaction. Mol. Plant Microbe Interact. 2004, 17, 6-15. [CrossRef]

122. Nichols, T.D.; Wolf, D.C.; Rogers, H.B.; Beyrouty, C.A.; Reynolds, C.M. Rhizosphere microbial populations in contaminated soils. Water Air Soil Pollut. 1997, 95, 165-178. [CrossRef]

123. Banks, M.K.; Kulakow, P.; Schwab, A.P.; Chen, Z.; Rathbone, K. Degradation of Crude Oil in the Rhizosphere of Sorghum bicolor. Int. J. Phytoremediat. 2003, 5, 225-234. [CrossRef]

124. Muratova, A.; Hübner, T.; Tischer, S.; Turkovskaya, O.; Möder, M.; Kuschk, P. Plant-Rhizosphere-Microflora Association During Phytoremediation of PAH-Contaminated Soil. Int. J. Phytoremediat. 2003, 5, 137-151. [CrossRef]

125. Khataee, A.; Movafeghi, A.; Torbati, S.; Lisar, S.S.; Zarei, M. Phytoremediation potential of duckweed (Lemna minor L.) in degradation of C.I. Acid Blue 92: Artificial neural network modeling. Ecotoxicol. Environ. Saf. 2012, 80, 291-298. [CrossRef]

126. Mendez, M.O.; Maier, R.M. Phytostabilization of Mine Tailings in Arid and Semiarid Environments-An Emerging Remediation Technology. Environ. Health Perspect. 2008, 116, 278-283. [CrossRef] [PubMed]

127. Bolan, N.S.; Park, J.H.; Robinson, B.; Naidu, R.; Huh, K.Y. Phytostabilization: A green approach to contaminant containment. In Advances in Agronomy; Academic Press: Cambridge, MA, USA, 2011; Volume 112, pp. 145-204. [CrossRef]

128. Zeng, P.; Guo, Z.; Cao, X.; Xiao, X.; Liu, Y.; Shi, L. Phytostabilization potential of ornamental plants grown in soil contaminated with cadmium. Int. J. Phytoremediat. 2018, 20, 311-320. [CrossRef]

129. Cunningham, S.D.; Berti, W.R.; Huang, J.W. Phytoremediation of contaminated soils. Trends Biotechnol. 1995, $13,393-397$. [CrossRef]

130. Limmer, M.A.; Burken, J.G. Phytovolatilization of Organic Contaminants. Environ. Sci. Technol. 2016, 50, 6632-6643. [CrossRef]

131. Terry, N.; Zayed, A.M.; De Souza, M.P.; Tarun, A.S. Selenium in higher plants. Annu. Rev. Plant Biol. 2000, 51, 401-432. [CrossRef]

132. Gordon, M.; Choe, N.; Duffy, J.; Ekuan, G.; Heilman, P.; Muiznieks, I.; Newman, L.; Ruszaj, M.; Shurtleff, B.B.; Strand, S.; et al. Phytoremediation of Trichloroethylene with Hybrid Poplars. ACS Symp. Ser. 1997, 106, 177-185. [CrossRef]

133. Wan, W.; Tan, J.; Wang, Y.; Qin, Y.; He, H.; Wu, H.; Zuo, W.; He, D. Responses of the rhizosphere bacterial community in acidic crop soil to $\mathrm{pH}$ : Changes in diversity, composition, interaction, and function. Sci. Total Environ. 2020, 700, 134418. [CrossRef] [PubMed]

134. Ju, W.; Liu, L.; Jin, X.; Duan, C.; Cui, Y.; Wang, J.; Ma, D.; Zhao, W.; Wang, Y.; Fang, L. Co-inoculation effect of plant-growthpromoting rhizobacteria and rhizobium on EDDS assisted phytoremediation of Cu contaminated soils. Chemosphere 2020, 254, 126724. [CrossRef]

135. Khan, N.; Bano, A. Role of PGPR in the Phytoremediation of Heavy Metals and Crop Growth under Municipal Wastewater Irrigation. In Phytoremediation (Management of Environmental Contaminants, Volume 6); Ansari, A.A., Gill, S.S., Gill, R., Lanza, G.R., Newman, L., Eds.; Springer: Cham, Switzerland, 2018; pp. 135-149. [CrossRef]

136. Guarino, F.; Miranda, A.; Castiglione, S.; Cicatelli, A. Arsenic phytovolatilization and epigenetic modifications in Arundo donax L. assisted by a PGPR consortium. Chemosphere 2020, 251, 126310. [CrossRef]

137. Nadeem, N.; Asif, R.; Ayyub, S.; Salman, S.; Shafique, F.; Ali, Q.; Malik, A. Role of rhizobacteria in phytoremediation of heavy metals. Biol. Clin. Sci. Res. J. 2020, 2020, e035.

138. Khan, N.; Zandi, P.; Ali, S.; Mehmood, A.; Shahid, M.A.; Yang, J. Impact of Salicylic Acid and PGPR on the Drought Tolerance and Phytoremediation Potential of Helianthus annus. Front. Microbiol. 2018, 9, 2507. [CrossRef] [PubMed]

139. Mesa-Marín, J.; Del-Saz, N.F.; Rodríguez-Llorente, I.D.; Redondo-Gómez, S.; Pajuelo, E.; Ribas-Carbó, M.; Mateos-Naranjo, E. PGPR Reduce Root Respiration and Oxidative Stress Enhancing Spartina maritima Root Growth and Heavy Metal Rhizoaccumulation. Front. Plant Sci. 2018, 9, 1500. [CrossRef]

140. Sang, M.; Jeong, J.-J.; Kim, J.; Kim, K. Growth promotion and root colonisation in pepper plants by phosphate-solubilising Chryseobacterium sp. strain ISE14 that suppresses Phytophthora blight. Ann. Appl. Biol. 2018, 172, 208-223. [CrossRef]

141. Hansda, A.; Kumar, V.; Anshumali, A.; Usmani, Z. Phytoremediation of heavy metals contaminated soil using plant growth promoting rhizobacteria (PGPR): A current perspective. Recent Res. Sci. Technol. 2014, 6, 131-134.

142. Patel, P.R.; Shaikh, S.S.; Sayyed, R.Z. Dynamism of PGPR in bioremediation and plant growth promotion in heavy metal contaminated soil. Indian J. Exp. Boil. 2016, 54, 286-290.

143. Javed, M.T.; Tanwir, K.; Akram, M.S.; Shahid, M.; Niazi, N.K.; Lindberg, S. Phytoremediation of Cadmium-Polluted Water/Sediment by Aquatic Macrophytes: Role of Plant-Induced pH Changes. Cadmium Toxic. Toler. Plants 2019, 495-529. [CrossRef]

144. Aisien, F.A.; Faleye, O.; Aisien, E.T. Phytoremediation of heavy metals in aqueous solutions. Leonardo J. Sci. 2010, 17, 37-46.

145. Lu, Q.; He, Z.L.; Graetz, D.A.; Stoffella, P.J.; Yang, X. Phytoremediation to remove nutrients and improve eutrophic stormwaters using water lettuce (Pistia stratiotes L.). Environ. Sci. Pollut. Res. 2010, 17, 84-96. [CrossRef] 
146. Devi, S.; Nandwal, A.; Angrish, R.; Arya, S.; Kumar, N.; Sharma, S. Phytoremediation potential of some halophytic species for soil salinity. Int. J. Phytoremediat. 2015, 18, 693-696. [CrossRef] [PubMed]

147. Rehman, S.; Abbas, G.; Shahid, M.; Saqib, M.; Farooq, A.B.U.; Hussain, M.; Murtaza, B.; Amjad, M.; Naeem, M.A.; Farooq, A. Effect of salinity on cadmium tolerance, ionic homeostasis and oxidative stress responses in conocarpus exposed to cadmium stress: Implications for phytoremediation. Ecotoxicol. Environ. Saf. 2019, 171, 146-153. [CrossRef] [PubMed]

148. Kumar, S.S.; Kadier, A.; Malyan, S.K.; Ahmad, A.; Bishnoi, N.R. Phytoremediation and rhizoremediation: Uptake, mobilization and sequestration of heavy metals by plants. In Plant-Microbe Interactions in Agro-Ecological Perspectives; Singh, D., Singh, H., Prabha, R., Eds.; Springer: Singapore, 2017; pp. 367-394.

149. Yavari, S.; Malakahmad, A.; Sapari, N.B.; Yavari, S. Nutrients balance for improvement of phytoremediation ability of teak seedlings (Tectona grandis). J. Plant Nutr. 2018, 41, 545-551. [CrossRef]

150. Al-Baldawi, I.A.; Abdullah, S.R.S.; Anuar, N.; Abu Hasan, H. Phytotransformation of methylene blue from water using aquatic plant (Azolla pinnata). Environ. Technol. Innov. 2018, 11, 15-22. [CrossRef]

151. Kumar, V.; Kumar, P.; Singh, J.; Kumar, P. Potential of water fern (Azolla pinnata R.Br.) in phytoremediation of integrated industrial effluent of SIIDCUL, Haridwar, India: Removal of physicochemical and heavy metal pollutants. Int. J. Phytoremediat. 2019, 22, 392-403. [CrossRef]

152. Odjegba, V.J.; Fasidi, I.O. Accumulation of Trace Elements by Pistia stratiotes: Implications for phytoremediation. Ecotoxicology 2004, 13, 637-646. [CrossRef]

153. Su, C.; Jiang, Y.; Li, F.; Yang, Y.; Lu, Q.; Zhang, T.; Hu, D.; Xu, Q. Investigation of subcellular distribution, physiological, and biochemical changes in Spirodela polyrhiza as a function of cadmium exposure. Environ. Exp. Bot. 2017, 142, 24-33. [CrossRef]

154. Singh, V.; Pandey, B.; Suthar, S. Phytotoxicity and degradation of antibiotic ofloxacin in duckweed (Spirodela polyrhiza) system. Ecotoxicol. Environ. Saf. 2019, 179, 88-95. [CrossRef] [PubMed]

155. He, Y.; Langenhoff, A.A.M.; Sutton, N.B.; Rijnaarts, H.H.M.; Blokland, M.H.; Chen, F.; Huber, C.; Schröder, P. Metabolism of Ibuprofen by Phragmites australis: Uptake and Phytodegradation. Environ. Sci. Technol. 2017, 51, 4576-4584. [CrossRef]

156. Rezania, S.; Park, J.; Rupani, P.F.; Darajeh, N.; Xu, X.; Shahrokhishahraki, R. Phytoremediation potential and control of Phragmites australis as a green phytomass: An overview. Environ. Sci. Pollut. Res. 2019, 26, 7428-7441. [CrossRef]

157. Ravi, R.; Rajendran, D.; Oh, W.-D.; Rasat, M.S.M.; Hamzah, Z.; Ishak, I.H.; Amin, M.F.M. The potential use of Azolla pinnata as an alternative bio-insecticide. Sci. Rep. 2020, 10, 19245. [CrossRef] [PubMed]

158. Das, M.; Ibn Rahim, F.; Hossain, A. Evaluation of Fresh Azolla pinnata as a Low-Cost Supplemental Feed for Thai Silver Barb Barbonymus gonionotus. Fishes 2018, 3, 15. [CrossRef]

159. Elrasoul, A.S.A.; Mousa, A.A.; Orabi, S.H.; Mohamed, M.A.E.-G.; Gad-Allah, S.M.; Almeer, R.; Abdel-Daim, M.M.; Khalifa, S.A.M.; El-Seedi, H.R.; Eldaim, M.A.A. Antioxidant, Anti-Inflammatory, and Anti-Apoptotic Effects of Azolla pinnata Ethanolic Extract against Lead-Induced Hepatotoxicity in Rats. Antioxidants 2020, 9, 1014. [CrossRef]

160. Tyagi, T.; Agarwal, M. Phytochemical screening and GC-MS analysis of bioactive constituents in the ethanolic extract of Pistia stratiotes L. and Eichhornia crassipes (Mart.) solms. J. Pharmacogn. Phytochem. 2017, 6, 195-206.

161. Kadir, A.A.; Abdullah, S.R.S.; Othman, B.A.; Abu Hasan, H.; Othman, A.R.; Imron, M.F.; Izzati Ismail, N.; Kurniawan, S.B. Dual function of Lemna minor and Azolla pinnata as phytoremediator for Palm Oil Mill Effluent and as feedstock. Chemosphere 2020, 259, 127468. [CrossRef]

162. Casebier, K. Water Purification System for Storm Drain Channels. U.S. Patent US7686956B1, 30 March 2010.

163. Sakakibara, Y.; Rodrigues dos, R.A.; Inagaki, Y.; Komori, M. Water Treatment Method Using Aquatic Plant. Japanese Patent WO2012029736A1, 8 March 2012. Available online: https:/ / patentscope.wipo.int/search/en/detail.jsf?docId=WO2012029736 (accessed on 13 January 2021).

164. Na, Z.; Yang, H.; Na, Z. Eichhornia Crassipes with Purple Root and Technology for Purifying Algae-Type Eutrophic Contaminated Water Bodies at Source. Chinese Patent CN102524084A, 4 July 2012.

165. Ma, Y.; Li, J.; Pan, B.; Zhou, H.; Ye, Z.; Shang, Y. Method for Removing Nitrogen and Phosphorus in Water Body by Hydrilla Verticillate. Chinese Patent CN102311173A, 11 January 2012.

166. Bauer, H.; Kozianka, F.; Endisch, S. Wastewater Purification Plant by Means of Plants. U.S. Patent US7718062B2, 18 May 2010.

167. Grieco, W.J. Marine Biomass Reactor and Methods Related Thereto. U.S. Patent US20180206423A1, 26 July 2018.

168. Ogden, M.H. Waste Treatment Systems. U.S. Patent US7361268B2, 22 April 2008.

169. Wallace, S.D.; Lambrecht, P.E. System and Method for Removing Pollutants from Water. U.S. Patent US6652743B2, 25 November 2003.

170. Gong, S. Method for Removing Soil Arsenic Pollution by Interplanting Pteris Vittate. Chinese Patent CN105945042A, 21 September 2016. 